\title{
Neuroplasticity and memory formation in major depressive disorder: An imaging genetics perspective on serotonin and BDNF
}

\author{
Manuel Kuhn, Ana Popovic and Lukas Pezawas* \\ Division of Biological Psychiatry, Department of Psychiatry and Psychotherapy, Medical University of Vienna, \\ Waehringer Guertel Vienna, Austria
}

\begin{abstract}
A vast number of imaging studies have demonstrated the impact of serotonin (5-HT) and brain-derived neurotrophic factor (BDNF) on emotion and memory-related networks in the context of Major Depressive Disorder (MDD). Underlying molecular mechanisms that affect the functionality of these networks have been examined in detail in animals and corroborate imaging findings. The crucial role of 5-HT and BDNF signaling in the context of MDD is reflected in the etiologic models of MDD such as the monoamine or neuroplasticity hypothesis as well as in pharmacological models of antidepressant response. While antidepressant drug treatment has been primarily linked to the modulation of emotion-related networks, cognitive behavioral therapy has been implicated in a top-down control of limbic structures. Initially, a simple lack of monoamines or BDNF has been proposed as causal factor of MDD etiology. However, recent findings suggest a much more complex neurobiology emphasizing epistatic and epigenetic mechanisms responsible for structural and functional changes observed in emotion and memory-related brain regions of healthy subjects and MDD patients. In this review, which focuses on neuroimaging studies in the context of MDD, the authors will provide a comprehensive overview of these networks as well as on the specific role of 5-HT and BDNF in their development and function.
\end{abstract}

Keywords: Neuroimaging, functional magnetic resonance imaging, neuroplasticity, serotonin transporter, memory, learning, epistasis, major depressive disorder, selective serotonin re-uptake inhibitor, tryptophan, SLC6A4, BDNF

\section{Introduction}

Major Depressive Disorder (MDD) is a clinically heterogeneous disorder of variable course that is characterized by depressive mood, lack of interest, disturbances of appetite, psychomotor function, sleepwake-cycle, etc. (American Psychiatric Association, 2000). While most symptoms are primarily emotionrelated, several cognitive symptoms are considered to be of diagnostic value, including suicidal ideation,

*Corresponding author: Lukas Pezawas, Department of Psychiatry and Psychotherapy, Medical University of Vienna, Waehringer Guertel 18-20, A-1090, Vienna, Austria. Tel.: +43 140400 3568; Fax: +43 140400 3099; E-mail: lukas.pezawas@meduniwien.ac.at. rumination as well as a diminished ability to think or concentrate (American Psychiatric Association, 2000). In its clinically deteriorated form, MDD can present itself as "pseudo-dementia", but typically MDD is not considered to be associated with a general impairment of cognitive functioning (Foland-Ross \& Gotlib, 2012). However, specific anomalies such as a deficit in cognitive control with regard to the processing of negative stimuli, or an enhanced memory for negatively valenced material are without doubt present (Foland-Ross \& Gotlib, 2012). Due to MDD's denotation as mood disorder, research has primarily focused on emotion-related brain regions, leading to the discovery of anatomical and functional alterations in limbic 
structures such as the anterior cingulate cortex (ACC), the amygdala, the hippocampus, and the orbitofrontal cortex (OFC) (Kupfer et al., 2012; Murray et al., 2011; Phillips et al., 2003a, b; Price \& Drevets, 2010, 2012). Apart from their role in emotion processing, some of these structures or interacting brain systems are also involved in cognitive control, learning, or memory formation. Notably, the hippocampus (McGaugh, 2000) and the amygdala (Davis \& Whalen, 2001) have been directly related to memory encoding. Others, such as the OFC and ACC, support learning (Hayden et al., 2009; Jones et al., 2012) or mediate a continuously updated prediction of future cognitive demands by retrieving memory content (Sheth et al., 2012). In addition, the dorsolateral prefrontal cortex (DLPFC) and ventrolateral prefrontal cortex (VLPFC), which are linked to memory retrieval and cognitive control are important in the regulation of subcortical limbic structures (Koenigs \& Grafman, 2009; Mitchell, 2011; Price \& Drevets, 2010, 2012).

Both, serotonergic neurotransmission (Homberg \& Lesch, 2011; Lesch \& Waider, 2012; Murphy, D.L. et al., 2008; Murphy, D.L. \& Lesch, 2008) as well as secretion of brain-derived neurotrophic factor (BDNF) (Castren \& Rantamaki, 2010; Duman \& Monteggia, 2006; Krishnan \& Nestler, 2010) have been demonstrated to modulate function and structure of memory and emotion-related brain regions in the context of MDD (Krishnan \& Nestler, 2008; Kupfer et al., 2012). Serotonergic effects are predominantly considered to be in line with the "monoamine hypothesis", which postulates a lack of synaptic monoamines in MDD (Delgado, 2000; Hirschfeld, 2000; Nutt, 2008; Ruhe et al., 2007). This model is supported by the clinical efficacy of tricyclic antidepressants and especially selective serotonin re-uptake inhibitors (SSRIs), the current first-line treatment of MDD (Davidson, 2010; Gelenberg, 2010; Kupfer et al., 2012). However, neither the delayed clinical therapeutic response of antidepressants (Bartova et al., 2010) nor the efficacy of non-pharmacological treatment modalities including cognitive behavioral therapy and electroconvulsive therapy can be sufficiently explained by this hypothesis (Castren, 2005). Therefore, alternative models such as the "neuroplasticity hypothesis" of MDD have been developed (Castren \& Rantamaki, 2010). Briefly, this hypothesis proposes the presence of dysfunctional neural circuitries in emotion-related brain regions in MDD that originate from defected BDNF secretion (Castren \& Rantamaki, 2010). Antidepressants are thought to facilitate the re-modeling of these dysfunctional neural circuitries, which ultimately leads to a relief of depressive symptoms (Masi \& Brovedani, 2011). Major support for this hypothesis stems from animal studies that found an increase of synaptic neuroplasticity during antidepressant drug treatment (Castren \& Rantamaki, 2010; Masi \& Brovedani, 2011; McEwen et al., 2010). Particularly, the antidepressant tianeptine has been a challenge for the monoamine hypothesis since some authors reported an enhanced 5-HT re-uptake or glutamate transmission under tianeptine treatment (McEwen et al., 2010).

Past (pre)clinical and neuroimaging studies have highlighted the importance of the above mentioned brain regions as well as serotonergic neurotransmission and BDNF secretion in the neurobiology of MDD and its treatment. Given the abundance of studies that have been conducted in these fields, we intend to provide an instructive literature overview comprising major research findings. We will outline basic anatomical and functional characteristics of neural circuitries involved in memory formation and emotion processing, which have been related to MDD. Moreover, a brief synopsis on how these neural circuitries are modulated by serotonin (5-HT) transmission, BDNF secretion and their molecular interactions will be provided. Particular attention will be paid to the distinct role of the 5-HT and BDNF signaling in memory formation and molecular mechanisms of learning that contribute to neuroplasticity. Finally, imaging studies examining brain systems level effects of SLC6A4 and BDNF will be discussed.

\section{Emotion-related brain regions}

Several cortical regions and subcortical structures have been repeatedly reported in studies investigating MDD patients (Price \& Drevets, 2010). The following section will briefly introduce their anatomy and function in the light of current concepts of MDD.

\subsection{Amygdala}

The amygdala is a large nuclear body consisting of several well-studied subnuclei that receive numerous cortical and subcortical inputs (LeDoux, 2000). It is considered a neural hub that is crucially involved in emotional and memory tasks such as facial emotion recognition (Adolphs et al., 1994; Morris, J.S. et al., 
1996), threat detection (Adolphs et al., 1995; Whalen et al., 1998), and fear conditioning (LaBar et al., 1998; LeDoux, 2007), and consequently determines behavior such as freezing or running for safety in animals. Moreover, the amygdala has been implicated in reward processing, aggression, maternal, sexual, and ingestive behaviors (LeDoux, 2007). With respect to cognitive functioning, it is thought to be involved in attention, perception, and memory formation by modulating the emotional salience of external stimuli (LeDoux, 2007). It is noteworthy that chronic stress exposure has been demonstrated to increase synaptic plasticity and reactivity of the amygdala in contrast to atrophic effects seen in the hippocampus (Pittenger \& Duman, 2008; Roozendaal et al., 2009). Given the important role of stress exposure for mental illness it is not surprising that amygdala dysfunction has been reported in various psychiatric conditions such as schizophrenia, autism, anxiety, and mood disorders (LeDoux, 2007). With respect to MDD, most studies found increased amygdala reactivity in patients with a concurrent depressive episode (Drevets et al., 2008a). Moreover, biased attention towards negative stimuli has repeatedly been shown in MDD and has been related to amygdala dysfunction (Browning et al., 2010; Everaert et al., 2012; Kupfer et al., 2012). Interestingly, the amygdala also alters anterior hippocampal activity and thereby indirectly affects memory formation (Disner et al., 2011; Fell \& Axmacher, 2011; LaBar \& Cabeza, 2006). However, results of morphometric studies measuring amygdala volume in MDD have been inconclusive so far (Bora et al., 2012; Drevets, 2003; Hamilton et al., 2008). Disease chronicity as well as medication status have been considered as confounding factors (Bora et al., 2012; Hamilton et al., 2008).

\subsection{Cingulate cortex}

The cingulate cortex (CC) comprises four anatomically distinct regions: anterior cingulate (ACC), midcingulate (MCC), posterior cingulate (PCC), and retrosplenial cortex (RSC), encompassing two subregions within each region (Palomero-Gallagher et al., 2009; Vogt, 2009). In the context of emotion and depression research, however, most attention has been paid to the subgenual ACC (sACC) and perigenual ACC (pACC), which are implicated in emotional and autonomic integration. Most importantly, the sACC has been related to processing of negative mood (Mayberg et al., 1999), treatment efficacy of SSRIs (Mayberg et al., 2000), deep brain stimulation (Holtzheimer et al., 2012; Mayberg et al., 2005), electroconvulsive (McCormick et al., 2007) as well as congitive behavioral therapy (DeRubeis et al., 2008; Disner et al., 2011). This notion has recently been supported by a publicly available meta-analytical tool that provides reverse inference of the importance of the ACC in functional neuroimaging studies thereby highlighting the relative specificity of this region for depressive mood (Yarkoni et al., 2011). Apart from that, the ACC has also been studied in the context of schizophrenia and pain (Lederbogen et al., 2011; Vogt, 2005). Furthermore, the ACC is heavily interconnected with the amygdala and other prefrontal cortical areas (Pizzagalli, 2011), thereby mediating the extinction of aversive memories (Livneh \& Paz, 2012; Margulies et al., 2007). Accordingly, neuroimaging literature underscoring the importance of the amygdala-ACC circuitry has attracted significant attention in emotion research (Drevets et al., 2008b; Pezawas et al., 2005). With regard to clinical studies, sACC volume reductions (Cotter et al., 2001; Ongur et al., 1998; Yucel et al., 2008) and activation increases (Drevets et al., 1997) have been amongst the first neurobiological findings reported in samples of MDD patients (Drevets et al., 2008b). Similar morphometric results have also been found in subjects with a family history of mood disorders (Boes et al., 2008; Hajek et al., 2008; Ongur et al., 1998).

\section{3. $O F C$}

The orbitofrontal cortex (OFC) predominantly receives inputs from sensory brain regions and is heavily interconnected with emotion- and memory-related neural structures such as amygdala, ventral striatum, and ACC. Neuroimaging studies have further supported a clear distinction between medial and lateral as well as anterior and posterior portions of the OFC (Kringelbach \& Rolls, 2004). In general, it is implicated in stimulus-reinforcer associations, goal-directed behavior, and reward conditioning (Kringelbach, 2005; Rolls \& Grabenhorst, 2008). Furthermore, OFC and ACC share important anatomical connections and functional similarities and are suggested to be involved in similar domains such as reinforcement-guided decision making, emotion and social behavior (Rushworth et al., 2007). With respect to MDD, OFC gray matter volume loss and increased metabolism in medial and lateral posterior regions have been reported (Drevets et al., 2008a). 


\subsection{Hippocampus}

The hippocampus consists of two main portions: the dentate gyrus and the Ammon's horn. The latter is histologically divided into four subregions CA1-CA4 (cornu ammonis). The hippocampus receives efferents from parahippocampal, entorhinal, and perirhinal cortices and is interconnected with several cortical regions including visual and auditory association areas as well as the prefrontal and parietal cortex. The subiculum of the hippocampus subserves as an output system, predominantly targeting cortical areas. Its tight interconnections with the amygdala and the OFC reflect the importance of the hippocampus in emotion processing (Rolls, 2007).

However, the hippocampus is best known for its prominent role in explicit memory formation (McGaugh, 2000; Rolls \& Kesner, 2006) as well as homeostatic adaptation to stressful environmental conditions (Kim, J.J. \& Diamond, 2002; Lopez et al., 1999). With respect to MDD research, hippocampal volume reductions and functional alterations have repeatedly been found in patients (Bremner et al., 2000; Colla et al., 2007; Duman \& Aghajanian, 2012; Eisch $\&$ Petrik, 2012; Masi \& Brovedani, 2011). These findings are in accordance with a known dysregulation of the hypothalamic-pituitary-adrenal (HPA) axis in MDD patients (de Kloet et al., 2005), which specifically affects the hippocampus due to its high sensitivity to glucocorticoid toxicity (McEwen, 2001). Moreover, hippocampal alterations have been related to memory deficits in MDD patients (Campbell \& Macqueen, 2004; Frodl et al., 2006).

\subsection{DLPFC and VLPFC}

The lateral prefrontal cortex anatomically comprises the ventrolateral (VLPFC; BA 44, 45, 47) and dorsolateral (DLPFC; BA 9, 46) PFC, which receives direct afferents from the mediodorsal thalamic nucleus together with the remaining PFC. The DLPFC and VLPFC are characterized by their dense projections to subcortical regions including limbic structures (Leh et al., 2007), thereby exerting a top-down control. It is noteworthy that the lateral PFC also receives indirect inputs from several areas including visual areas, OFC as well as subcortical regions such as the amygdala and hippocampus, among others (Fuster, 2001). DLPFC and VLPFC are responsible for executive functions and the processing of external stimuli in terms of their relevance for behavioral changes (Sakagami \& Pan, 2007). Together with the ACC, the VLPFC orchestrates the cognitive control of emotions, via both, bottom up and top down regulation (Ochsner et al., 2004; Price \& Drevets, 2010). It is of clinical relevance that the modulation of these brain areas is thought to be cricital for the efficacy of cognitive behavioral therapy in MDD patients (Disner et al., 2011). Interestingly, the left VLPFC has foremost been implicated in cognitive control of negative and amygdala-driven emotion, whereas the right VLPFC has been associated with emotion-related motor inhibition (Levy \& Wagner, 2011). Moreover, the VLPFC and the amygdala are part of a brain system that monitors and selects responses to threats (Hariri et al., 2003b). Contrarily, the DLPFC has predominately been demonstrated to be involved in planning (Crescentini et al., 2012), action selection (Rowe et al., 2000) and working memory (Goldman-Rakic, 1997). It is therefore considered to be "a place, where the past and the future meet", because it creates memories from sensory inputs and it assembles a motor plan of action (Fuster, 2001). Left PFC lesions have been more frequently associated with depression than with contralateral brain lesions (Morris, M.K. et al., 1992). Additionally, decreased working memory performance in MDD patients has been related to hypoactivation and gray matter volume reduction in these areas (Goldstein et al., 2011). The latter finding is thought to result from a loss of dendritic spines, dendrites and synapses, due to decreased expression of synapse-related genes (Kang et al., 2012). Furthermore, limited evidence suggests that SSRI treatment might normalize hypoactivity (Fales et al., 2009) and gray matter loss (Kang et al., 2012) in both regions.

\section{Serotonin}

Serotonin (5-hydroxytryptamine, 5-HT) is primarily found in the gastrointestinal tract (Dhasmana et al., 1993), the blood platelets (Hranilovic et al., 1996), and in the brain (Barnes \& Sharp, 1999). It is actively removed from extracellular space by the transmembrane 5-HT transporter protein (5-HTT), followed by monoaminoxidase-A (MAO-A) intracellular degradation (Youdim et al., 2006). Neuronal serotonergic cells project to virtually every brain area (Gaspar et al., 2003; Kiyasova \& Gaspar, 2011). However, 5-HTT availability is not equally distributed throughout the brain and shows high densities in subcortical limbic 
structures (e.g., hippocampus, amygdala) (O'Rourke \& Fudge, 2006; Saulin et al., 2012) and cortically along the midline of the brain (Kranz et al., 2010; Yokoyama et al., 2010), and specifically in the sACC (Varnas et al., 2004). This is also supported by publicly available human gene expression maps of SLC6A4 (Hawrylycz et al., 2012). While neural 5-HTTs are terminating synaptic 5-HT actions, postsynaptic 5-HT receptors are initiating an intracellular and mostly Gprotein coupled cascade that may lead to inhibitory or excitatory neural responses (Hoyer et al., 2002). Up to now, seven 5-HT receptor families and a number of specific subtypes have been characterized (Nichols $\&$ Nichols, 2008). Similar to 5-HTT, 5-HT receptors are highly expressed in cortico-limbic regions, specifically hippocampus, ACC, and entorhinal cortex (Bose et al., 2011; Palomero-Gallagher et al., 2009), and accordingly, correlate to some degree with regional 5-HTT availability (Banerjee et al., 2007; Bose et al., 2011; Nichols \& Nichols, 2008). In the context of MDD research, most attention has been paid to the $5-\mathrm{HT}_{1 \mathrm{~A}}$ receptor, because it is thought to mediate antidepressant drug action (Bortolozzi et al., 2012; Lemonde et al., 2004; Meltzer et al., 2004; Richardson-Jones et al., 2010; Spindelegger et al., 2009) as well as behavioral phenotypes related to MDD (Blier \& Ward, 2003). It is noteworthy that 5-HT $1 \mathrm{~A}$ receptors can be found post-synaptically as well as presynaptically thereby controlling 5-HT transmission as auto-receptors (Albert et al., 2011; Lundberg et al., 2007; Puig \& Gulledge, 2011).

Serotonin signaling modulates neuronal processing of crucial vegetative and emotional functions including mood, anxiety, appetite, sexual drive and function, and sleep-wake cycle (Canli \& Lesch, 2007) as well as executive functions and memory (Puig \& Gulledge, 2011). Furthermore, 5-HT is a neurodevelopmental factor (Gaspar et al., 2003; Gross \& Hen, 2004; Lesch $\&$ Waider, 2012), relevant for the development of glutamatergic projection neurons (Dooley et al., 1997), migration of serotonergic and non-serotonergic cells (Riccio et al., 2009), and the modulation of fetal forebrain development via a transient placental source (Bonnin et al., 2011). Interestingly, 5-HTT is additionally expressed in non-serotonergic neurons during early-life stages thereby promoting these developmental effects (Gaspar et al., 2003). On a behavioral level, it has been demonstrated that a transient pharmacological inhibition of 5-HTT in early-life alters emotional behavior in adult mice (Ansorge et al., 2004). Addi- tionally, 5-HTT is also implicated in neuroplasticity in adults (Lesch \& Waider, 2012) and animal work has demonstrated that SSRI-induced neuroplasticity can be blocked by drugs which decrease neural activity (Maya Vetencourt et al., 2008). Apart from that, reduced synaptic 5-HT availability induced by acute tryptophan depletion (ATD) has been associated with depressed mood in human adults (Ruhe et al., 2007), specifically in subjects at high risk for MDD (Feder et al., 2011; Neumeister et al., 2004). Similarly, ATD has been found to increase anxiety but not fear (Robinson et al., 2012). Compellingly, memory processes such as fear conditioning have been reported to be attenuated (Hindi Attar et al., 2012), which contrasts with findings in other memory domains including autobiographical (Haddad et al., 2009) and episodic memory (Ruhe et al., 2012). Eventually, ATD has been linked to alterations of stimulus-reward association (Rogers et al., 1999), emotional (Merens et al., 2008), reversal (Murphy, F.C. et al., 2002), and verbal learning (Evers et al., 2005).

Since the 5-HTT is the "bottle-neck" for the termination of neural 5-HT actions, it is not surprising that its pharmacological inhibition by SSRIs emerged as first-line treatment of MDD (American Psychiatric Association, 2010). Maximal synaptic 5-HT concentrations occur immediately after acute SSRI administration and behavioral changes such as increased anxiety (Browning et al., 2007; Burghardt et al., 2007) or even suicidal behavior (Hetrick et al., 2007) have been reported. However, clinically observable antidepressant effects such as a decrease in anxiety and a normalization of depressive mood do not occur before the second week of treatment (Kupfer et al., 2012). Contrarily, on a brain level, 5-HT-induced neural activation can already be detected ahead of the clinical response with fMRI (Klomp et al., 2012; Preece et al., 2009), which is corroborated by human studies in healthy subjects (Del-Ben et al., 2005; McKie et al., 2005) and MDD patients (Anderson et al., 2011). These studies suggest that acute SSRI administration is followed by an initial activation peak within the amygdala that normalizes or even attenuates with chronic SSRI treatment (Arce et al., 2008; Bigos et al., 2008; Harmer et al., 2006; Ruhe et al., 2012; Windischberger et al., 2010). Analougous results have been shown for the ACC (Harmer et al., 2006; McKie et al., 2005) and the hippocampus (Harmer et al., 2006; McKie et al., 2005; Rose et al., 2006; Windischberger et al., 2010). Opposing effects have been 
reported for the OFC (Del-Ben et al., 2005; McCabe et al., 2010; McKie et al., 2005). On a brain systems level, decreased functional connectivity between ventral medial prefrontal cortex and amygdala has been found under SSRI treatment in healthy subjects (McCabe \& Mishor, 2011). In the context of MDD, an initial reduction of amygdala-ACC functional coupling (Anand et al., 2005) has been reported to be reversible by chronic SSRI treatment (Chen, C.H. et al., 2008). Likewise, stress-induced hippocampal atrophy has been demonstrated to be reversible under antidepressant treatment (Meyer, 2007), however contradictory results exist (Vythilingam et al., 2004).

The human 5-HTT protein is encoded by a single gene (SLC6A4) that possesses several polymorphic regions affecting its expression and function (Lesch et al., 1996; Murphy, D.L. \& Lesch, 2008). Specifically, a variable number of tandem repeats (VNTR) polymorphism (5-HTTLPR) within the promoter region of SLC6A4, impacting on its transcriptional activity (Lesch \& Mossner, 2006), has been investigated in countless studies in the context of mental illness (Caspi et al., 2010). Comparisons of 5-HTT binding in subjects with different 5-HTTLPR genotypes have been controversial since some studies have not been able to demonstrate any impact of genotype on 5-HTT function in vivo (Murthy et al., 2010; Parsey et al., 2006; Shioe et al., 2003) or post-mortem tissue (Mann et al., 2000). However, such lack of effects of 5HTTLPR on altered 5-HTT binding can be explained by developmental or environmental rather than direct effects of 5-HTTLPR on adult serotonergic neurotransmission (Gaspar et al., 2003; Kalbitzer et al., 2010; Parsey et al., 2006; Willeit et al., 2008). Moreover, 5-HTTLPR genotypes seem to be affected by epigenetic mechanisms (Alasaari et al., 2012; Kinnally et al., 2010; van IJzendoorn et al., 2010), which could further explain inconclusive findings. Originally, 5HTTLPR has been considered to comprise two allelic variations: a short (S) and a long (L) allele, the latter resulting in higher transcriptional efficacy (Lesch et al., 1996). Today, it has become a gold standard to utilize a tri-allelic classification of 5-HTTLPR, taking into account a substitution polymorphism (rs25531) within the $\mathrm{L}$ allele. High transcriptional activity has been found for the so-called $\mathrm{L}_{\mathrm{A}}$ allele, which contrasts the $\mathrm{L}_{\mathrm{G}}$ allele that is more similar to the $\mathrm{S}$ allele (Bevilacqua \& Goldman, 2011; Hu \& Russek, 2008). Frequencies of the $S$ allele vary dramatically between ethnicities, with about two thirds of $\mathrm{S}$ allele carriers of European ancestry and significantly higher number in Asian populations (Kunugi et al., 1997). With regard to behavioral correlates of 5-HTTLPR, predominantly increased neuroticism in S allele carriers has been reported (Lesch et al., 1996; Schinka et al., 2004; Sen et al., 2004; Shifman et al., 2008), although effect sizes appear to be small on a behavioral level (Murphy, S.E. et al., 2012; Shifman et al., 2008). While neuroticism is only considered to be a risk factor for MDD (Kendler et al., 2004), the development of the fullblown picture of MDD has been described in S allele carriers in the presence of environmental adversity (Caspi et al., 2003). This gene-environment interaction has been replicated in several studies (Eley et al., 2004) along with comparable results in PTSD investigating effects of childhood adversity (Xie et al., 2012). However, some studies failed to find a 5-HTTLPRenvironment interaction (Levinson, 2006). Given this inconsistency, meta-analytical studies have been conducted, some of which did not support such an effect (Munafo et al., 2009; Risch et al., 2009). These findings have been challenged by a recent meta-analysis that identified the presence of a selection bias within previous meta-analyses, thereby supporting the original finding of 5-HTTLPR-environment interactions (Karg et al., 2011). This conclusion should be corroborated by future animal work investigating the molecular mechanisms of such a gene-environment interaction (Alasaari et al., 2012; Caspi et al., 2010; Jasinska et al., 2012; Miller et al., 2012). 5-HTTLPR genotyping has also been linked to SSRI treatment response in several pharmacogenetic association studies (Serretti et al., 2011), however conflicting results exist (Rabl et al., 2010). Apart from replicated 5-HTTLPR effects on limbic structures, evidence from recent animal studies hints at 5-HTTLPR mediated effects on prefrontal executive areas that show beneficial impacts of the $S$ allele on cognitive processes such as reversal learning (Finger et al., 2007; Homberg \& Lesch, 2011). This finding might also serve as a possible explanation, why the common $\mathrm{S}$ allele has been selected by evolutionary pressure (Homberg \& Lesch, 2011).

Over the past decade, numerous functional and anatomical neuroimaging studies have investigated 5-HTTLPR brain effects by applying an "imaging genetics" approach (Scharinger et al., 2010) (Fig. 1). Originally, healthy $\mathrm{S}$ allele carriers have been found to exhibit an exaggerated amygdala response induced by the presentation of fearful faces (Hariri et al., 2002), a finding that has repeatedly been replicated (Scharinger 


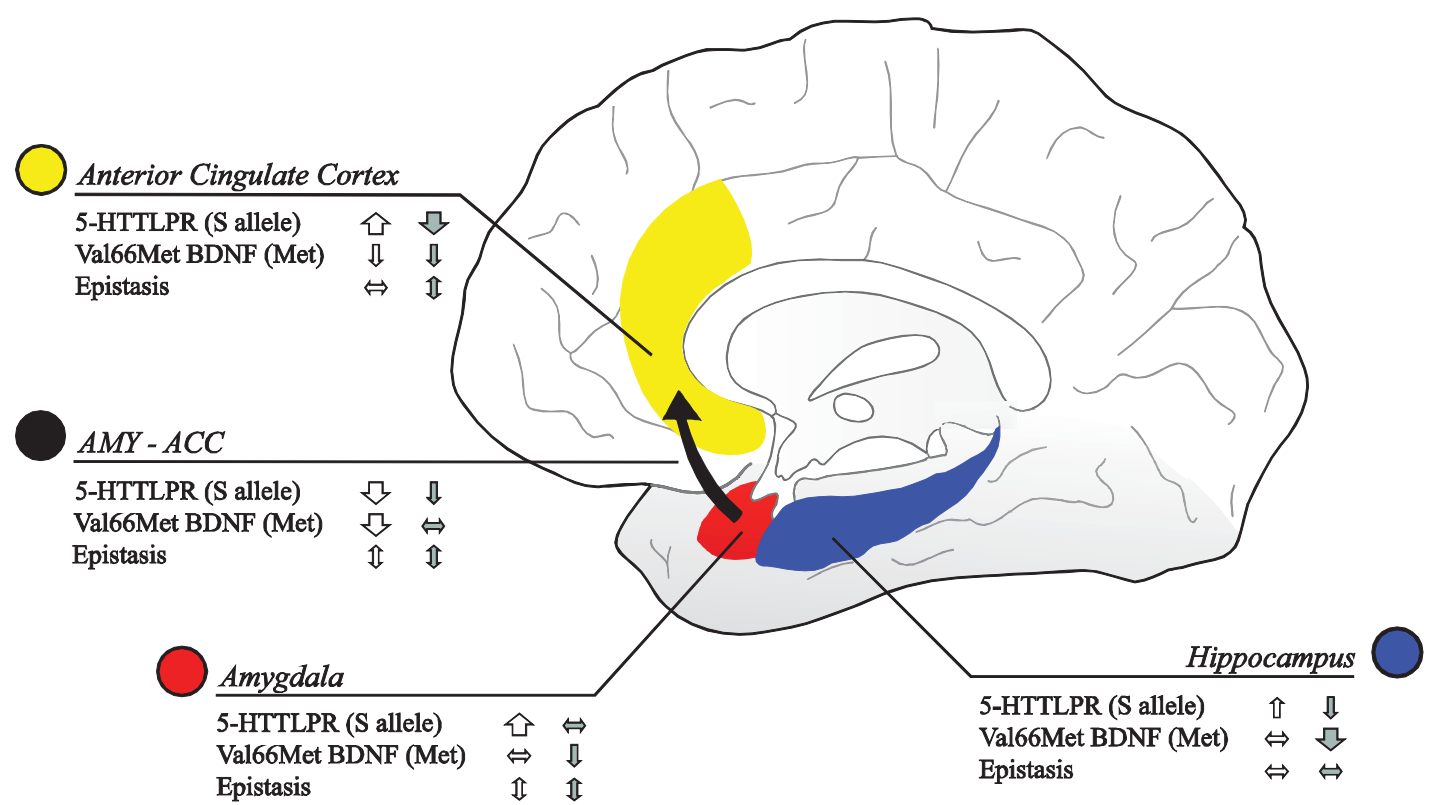

Fig. 1. Overview of functional and structural 5-HTTLPR and Val66Met BDNF effects in healthy subjects reported by imaging genetics studies. 5-HTTLPR (S allele): S allele > L/L genotype of 5-HTTLPR; Val66Met BDNF (Met): Met allele > Val/Val genotype of Val66Met BDNF; Epistasis: Epistasis between SCL6A4 and BDNF; arrow direction indicates increase or decrease of BOLD signal or gray matter volume; arrow thickness indicates number or significance of study results; vertical double arrows indicate significant epistasis effects; horizontal double arrows indicate inconclusive or lacking results. Gray arrows represent results of structural studies and white arrows represent results of functional studies.

et al., 2010). Similarly, increased amygdala activation during rest has been found in $\mathrm{S}$ allele carriers (Canli et al., 2005; Rao et al., 2007; von dem Hagen et al., 2011). Meta-analytic data suggest that gene effects of this kind are overall smaller than originally anticipated (Murphy, S.E. et al., 2012). Furthermore, functional connectivity studies have highlighted a reduced coupling of amygdala and SACC activity in 5HTTLPR S allele carriers (Heinz et al., 2005; Lemogne et al., 2011; Pezawas et al., 2005; Roiser et al., 2009; Shah et al., 2009), while one study failed to detect a genotype-driven alteration of amygdala-sACC connectivity (O'Nions et al., 2011). This reduction of amygdala-sACC coupling seems to be primarily driven by developmental effects of 5-HTTLPR on sACC volume (Frodl et al., 2008a; Jedema et al., 2010; Migliarini et al., 2012; Pezawas et al., 2005; Selvaraj et al., 2011), which accords with behavioral changes such as increased neuroticism (Cremers et al., 2010; Haas et al., 2007; Pezawas et al., 2005). Previous studies have shown that a reduction of amygdalasACC coupling leads to dis-inhibition of a feedback loop resulting in increased amygdala activity (Hariri et al., 2002; Heinz et al., 2005; Munafo et al., 2008; Pezawas et al., 2005). Additionally, imaging genetics studies have examined 5-HTTLPR effects on brain areas involved in executive functions (Homberg \& Lesch, 2011). Results show increases in DLPFC activity in $\mathrm{S}$ allele carriers during a working memory task (Jonassen et al., 2012) and in VLPFC activity during cognitive appraisal of emotions (Firk et al., 2012; Surguladze et al., 2008). Besides, hippocampal activation increases have been reported during threat anticipation (Drabant et al., 2012; Smolka et al., 2007), whereas volumetric reductions have been observed in healthy S-allele carriers (Frodl et al., 2008a) in this region. Yet, patient studies revealed opposing results and showed hippocampal volume loss for L homozygote patients (Frodl et al., 2004; Frodl et al., 2008b), which is not suprising given the role of stress-related methylation (Alasaari et al., 2012; Kinnally et al., 2010; van IJzendoorn et al., 2010). Finally, supportive evidence exists for an increased vulnerability of the hippocampus with regard to environmental adversity in S allele carriers (Canli et al., 2006; Frodl et al., 2010). 


\section{BDNF}

Human brain tissue expresses four different neurotrophins (Lu, B. et al., 2005). The most extensively investigated neurotrophin, BDNF, exhibits its highest expression in the hippocampus, amygdala, neocortex, and the cerebellum (Lessmann et al., 2003). BDNF is an important neurodevelopmental factor and essential for cholinergic, GABAergic, dopaminergic, as well as serotonergic neuronal development and survival. This highlights its tight relationship to neuropsychiatric diseases such as schizophrenia, mood disorders, Huntington's disease, Alzheimer's disease etc. (Autry \& Monteggia, 2012). The BDNF protein is coded by a single gene $(B D N F)$, which undergoes a complex transcription process before its mature form is made available. Its expression is activated and regulated by activity- and calcium-sensitive transcription factors including the cAMP response-element binding protein (CREB) (Autry \& Monteggia, 2012). The BDNF protein itself evolves from its precursor pro-BDNF and is synthesized in the endoplasmatic reticulum. Thereafter, it is packed into neuronal vesicles and forwarded to axonal terminals or dendrites, where it is released in an activity-dependent manner (Lu, B. et al., 2005). Notably, selective expression and secretion of pro-BDNF and mature BDNF are cell type dependent and activate two different signaling pathways, where pro-BDNF has been found to induce apoptosis by selectively activating the lowaffinity p75 neurotrophin receptor (p75NTR). Mature $\mathrm{BDNF}$, on the other hand, promotes neurotrophic and anti-apoptotic effects by binding to the high-affinity tropomyosin-related kinase receptor type B (TrkB) receptor, located at pre- as well as postsynaptic sites (Autry \& Monteggia, 2012). The independent reciprocal effects of pro- and mature BDNF have been called 'yin \& yang' principle (Lu, B. et al., 2005) since both constitute a potential mechanism for essential structural and functional alterations during development but also in the context of neuroplasticity in the adult brain (Autry \& Monteggia, 2012; Poo, 2001). Moreover, BDNF has also been implicated in the biological mechanism of long-term memory formation (Barco et al., 2005). While mature BDNF has been associated with long-term potentiation (LTP), an electrophysiological correlate of long-term memory consolidation and learning, pro-BDNF signaling has been related to long-term depression (LTD) representing memory extinction and impairment (Autry \& Monteggia, 2012;
Lu, B. et al., 2005; Lu, Y. et al., 2008; Malenka \& Bear, 2004).

In line with these molecular neuroplasticity effects, altered regional BDNF concentrations have been suggested to impact on episode onset, re-occurrence, and treatment response of mood disorders via sensitization and kindling-like mechanisms (Post, 2007). BDNF alterations were further found in the reward and motivation regions of the brain such as the nucleus accumbens (NAcc) in mice that have been exposed to social defeat stress (Krishnan et al., 2007). These findings are in accordance with post mortem data of NAcc brain tissue in depressed humans (Krishnan et al., 2007). Eventually, it has early been recognized that hippocampal $B D N F$ transcription significantly decreases during stress, which is accompanied by a reduction of BDNF blood levels, specifically in MDD patients (Bartova et al., 2010; Molendijk et al., 2011; Schmidt et al., 2011). While some authors consider observed BDNF alterations to be a state feature reflecting biological changes accompanying acute stress (Bocchio-Chiavetto et al., 2010; Molendijk et al., 2011), others suggest that such alterations rather represent a trait marker of MDD (Piccinni et al., 2008). Complementary evidence stems from antidepressant drug treatment and electroconvulsive therapy studies in animals that found increased BDNF expression (Duman et al., 2000), whereas human studies found a normalization of BDNF plasma levels (Brunoni et al., 2008) that predicted antidepressant treatment outcome (Dreimuller et al., 2012). This modulatory effect of BDNF on antidepressant drug response is supported by animal studies that demonstrated its dependence on BDNF genotypes in BDNF-knockout mice models (Saarelainen et al., 2003). Furthermore, intra-cerebral BDNF infusion in animals has shown to facilitate the efficacy of antidepressants (Kozisek et al., 2008). However, several animal and human studies have not been able to detect or replicate such effects (Groves, 2007; Schmidt et al., 2011). Therefore, final conclusions with regard to the validity of the neuroplasticity hypothesis of depression and its biological mechanisms cannot be drawn at this moment. Hence, further evidence is needed, before plasma BDNF levels can possibly be used for clinical applications such as diagnostics or personalized treatment regimes (Hashimoto, K., 2010; Kapur et al., 2012; Nagahara \& Tuszynski, 2011). Recent research indicates that the relationship between BDNF secretion and clinically depressive phenotypes is far more complex than originally anticipated 
(Castren \& Rantamaki, 2010). Specifically, a mere BDNF level - clinical phenotype association seems oversimplified and neglects the fact that BDNF mediated neural remodeling is dependent on appropriate environmental stimulation (Castren \& Rantamaki, 2010). Rather than explaining depression by deficiencies of BDNF in cortical or hippocampal brain regions, activity-dependent BDNF expression would facilitate a process, which impacts on neuronal networks under environmental guidance in a way that enables optimal adaptation to environmental conditions. This might also explain why antidepressants affect mood only in patients and not in healthy subjects (Castren \& Rantamaki, 2010).

A genomic deletion of a region including $B D N F$ assessed by a microarray study has been described as highly penetrant, and hemizygosity of $B D N F$ has been found to contribute to variable psychiatric phenotypes including anxiety, behavioral, and mood disorders (Ernst et al., 2012). However, previous studies have predominantly focused on investigating functional polymorphisms within $B D N F$, and several genetic variants of $B D N F$ have been identified so far (Licinio et al., 2009). Notwithstanding, only Val66Met BDNF, a substitution polymorphism in the 5 ' pro-domain of $B D N F$, has been thoroughly explored. The Met allele of Val66Met BDNF has clearly been linked to defective BDNF signaling on a cellular level showing reduced intracellular trafficking to distal dendrites, failure to distribute BDNF to secretory granules, and lower depolarization-induced secretion (Chen, Z.Y. et al., 2004; Egan et al., 2003). Complementary evidence stems from neuroimaging studies that demonstrated the impact of Val66Met BDNF on brain regions crucial for learning, memory, and emotions. In healthy subjects the most observed and replicated finding has been hippocampal volume loss in Met allele carriers, which is supported by meta-analytical data (Hajek et al., 2012; Kambeitz et al., 2012; Molendijk et al., 2012a). Of particular relevance, early studies found higher effect sizes than later ones (Molendijk et al., 2012a). With regard to patient sample studies, several authors reported comparable results (Chepenik et al., 2009; Eker et al., 2010; Frodl et al., 2007; Gatt et al., 2009; Lau et al., 2010; Matsuo et al., 2009; Szeszko et al., 2005), while others could not replicate previous findings in mood disorder samples (Cole et al., 2011; Gerritsen et al., 2012; Jessen et al., 2009; Karnik et al., 2010; Nemoto et al., 2006; Richter-Schmidinger et al., 2011). While findings in healthy subjects are considered to be conclusive (Hajek et al., 2012; Kambeitz et al., 2012), no conclusions can be drawn from patient studies yet (Scharinger et al., 2010). This might be due to diagnostic heterogeneity of MDD, disease course and medication effects (Bigos \& Weinberger, 2010), and to a lesser degree to stress-related epigenetic effects (Unternaehrer et al., 2012). These findings are further underlined by studies reporting BDNF interactions with diagnosis (Koolschijn et al., 2010), personality (Joffe et al., 2009), and life events (Gatt et al., 2009). Moreover, Val66Met BDNF genotypes have shown to affect hippocampal function within several memory paradigms (Egan et al., 2003; Hariri et al., 2003a; Hashimoto, R. et al., 2008; Schofield et al., 2009). On a behavioral level, particularly Met carriers of Val66Met BDNF have shown reductions in episodic memory (Dempster et al., 2005; Egan et al., 2003; Hariri et al., 2003a), working memory (Gatt et al., 2009; Richter-Schmidinger et al., 2011), and verbal learning (Cathomas et al., 2010; Goldberg et al., 2008; Ho et al., 2006; Schofield et al., 2009). These findings are in line with animal studies highlighting a specific role of BDNF in the preservation of hippocampal functional integrity that is related to memory processing and depressive mood (Heldt et al., 2007; Molendijk et al., 2012b; Monteggia et al., 2004; Saxe et al., 2006). Yet, some studies failed to detect Val66Met BDNF effects on working (Hansell et al., 2007) or verbal memory (Matsuo et al., 2009) as well as other memory-related tasks (Karnik et al., 2010). This is further supported by a recent meta-analysis, which found lacking evidence for Val66Met BDNF mediated impairment in memory processing, general cognitive ability, cognitive fluency, visual processing, and executive functioning (Mandelman \& Grigorenko, 2012).

In contrast, other limbic structures have less consistently been related to differential effects of $B D N F$ genotypes. While the majority of studies found no evidence for amygdala volume reductions (Frodl et al., 2007; Gerritsen et al., 2012; Matsuo et al., 2009; Pezawas et al., 2004; Schofield et al., 2009), few authors observed amygdala volume loss in healthy Met allele carriers (Gatt et al., 2009; Sublette et al., 2008). Similarly, conflicting results exist with respect to amygdala function and the specific role of Val66Met BDNF genotypes (Gasic et al., 2009; Montag et al., 2008; Wang et al., 2012). Moreover, only one animal study supports Met allele induced amygdala reactivity (Chen, Z.Y. et al., 2006), whereas most human fMRI studies 
report no influence of Val66Met BDNF on amygdala activation (Egan et al., 2003; Hariri et al., 2003a; Hashimoto, R. et al., 2008; Schofield et al., 2009). However, Val66Met BDNF seems to shape amygdaladependent extinction learning (Soliman et al., 2010) and memory formation for biologically salient stimuli (van Wingen et al., 2010). Additionally, limited evidence is available suggesting that Val66Met BDNF impacts on ACC structure (Gerritsen et al., 2012) and function (Soliman et al., 2010). Furthermore, no conclusions can be currently drawn from imaging studies investigating white matter tract connectivity (Chiang et al., 2011; Montag et al., 2010). Eventually, pilot data suggest that Val homozygotes exhibit stronger resting state functional connectivity between PCC and precuneus, a neural circuitry involved in episodic memory retrieval (Jang et al., 2012).

\section{Complex interactions of $S L C 6 A 4$ and $B D N F$}

Acute episodes of MDD are frequently triggered by adverse life-events (Kupfer et al., 2012). Apart from that, MDD is undoubtedly heritable, given the known accumulation of cases in families (Kupfer et al., 2012; Wong \& Licinio, 2001). However, the identification of the genetic origin of MDD is challenging since single genetic variants explain only a very small proportion of the variance of this psychiatric entity (Rabl et al., 2010). Therefore, it is necessary to consider the full complexity of gene effects and their linkage to psychopathology (Meyer-Lindenberg, 2012). Examples depicting the biological complexity of clinical phenotypes are gene-environment interactions, pleiotropy, imprinting, epistasis, epigenetics, heterogeneity, and polygenicity (Badcock \& Crespi, 2008; Goldman et al., 2005; Houston et al., 2013; Levenson \& Sweatt, 2005; Moore et al., 2013; Puckett \& Lubin, 2011; Skipper, 2011; Sultan \& Day, 2011; Tsankova et al., 2007). It has been highlighted that most intermediate phenotypes are likely not per se less genetically complex than behavioral phenotypes (Flint \& Munafo, 2007; Meyer-Lindenberg \& Weinberger, 2006). However, since intermediate phenotypes are thought to be biologically more valid, they might be more suitable for the study of genetic complexity on a brain systems level and its relation to behavioral phenotypes.

First attempts to unravel the complex genetic effects on human behavior have made significant progress, particularly concerning molecular interactions of
BDNF and 5-HT signaling pathways (Martinowich \& Lu, 2008; Nestler et al., 2002). Briefly, TrkB-mediated BDNF effects are thought to promote the development, functional integrity and axonal sprouting of 5-HT neurons by retrograde BDNF transportation to the raphe nuclei as well as by enhancing the activitydependent 5-HT release. Post-synaptic 5-HT signaling leads to subsequent activation of the intracellular transcription factor CREB that promotes BDNF synthesis (Martinowich \& Lu, 2008). Therefore, it has been hypothesized that SSRI-induced increases of synaptic 5-HT stimulate BDNF secretion via postsynaptic 5HT receptors leading to a re-modeling of dysfunctional emotion brain circuitries (Martinowich \& Lu, 2008).

On a genetic level, such a molecular conversion of two signaling pathways would be indicative for epistasis, which refers to the interaction of two or more genes that exert combined influences on a disease or phenotype (Cordell, 2002). From a statistical point of view, it refers to a combined gene effect that is not simply additive in nature (Cordell, 2002). In order to study $S L C 6 A 4 \times B D N F$ epistasis, scientists utilized genetically engineered mouse models involving homozygous/heterozygous SLC6A4 and heterozygous BDNF knockouts (Murphy, D.L. et al., 2003). Results have demonstrated epistasis for SLC6A4 and BDNF in key emotion regions of the brain (Murphy, D.L. et al., 2003; Ren-Patterson et al., 2005), which goes along with alterations of stress hormone secretion (RenPatterson et al., 2005). Similarly, BDNF and SLC6A4 epistasis has been found to be accountable for individual stress responses in preschoolers (Dougherty et al., 2010). Only a few human imaging genetics studies have investigated epistatic effects so far. The first study reporting epistasis on an intermediate phenotype level revealed a protective effect of the BDNF Met allele on 5-HTTLPR S allele-induced anatomical alterations within the sACC-amygdala circuitry in healthy subjects (Pezawas et al., 2008). This finding corroborates the hypothesis that $S L C 6 A 4 \times B D N F$ interactions specifically affect negative emotion processing (Pezawas et al., 2008). However, opposing imaging results exist for functional (Wang et al., 2012) as well as for structural studies (Cole et al., 2011). Notably, other imaging modalities such as manual tracing or 3D-shape analysis have been used in this structural study (Cole et al., 2011), which differes from the original report utlizing voxel-based morphometry (Pezawas et al., 2008).

Another complex genetic mechanism, the geneenvironment (GxE) interaction, has also been studied 
on various biological levels (Scharinger et al., 2010). In line with the idea of a common interaction between $S L C 6 A 4, B D N F$, and environmental stress, one author reports that the onset of a depressive episode can be predicted by cortisol levels for carriers of the 5-HTTLPR S allele as well as for BDNF Val homozygotes (Goodyer et al., 2010). Additionaly, it has been suggested that stress-induced low transcription rates of BDNF can be reversed by SSRIs (Duman \& Monteggia, 2006; Martinowich \& Lu, 2008). Similarly, Val66MET BDNF has been shown to alter stress vulnerability and response to antidepressants in animals (Yu et al., 2012). A more elaborated model has been recently proposed arguing that genetic variability of SLC6A4 resulting in individual 5-HT re-uptake efficiency alters the balance in the amygdala-ventromedial prefrontal cortex (VMPFC)-dorsal raphe (DR) circuitry underlying stressor reactivity and emotion regulation (Jasinska et al., 2012). The repeated exposure to uncontrollable stressors in MDD patients leads then to hypereactivity to stress in the amygdala and hyporeactivity of the regulation of emotion in the VMPFC, which is mediated by activity-dependent neuroplasticity (Jasinska et al., 2012). Thus, neuronal 5-HTTLPR effects depend on exposure to stressors (Jasinska et al., 2012), which is in accordance with clinical studies that reported 5HTTLPR S allele carriers to be at an increased risk for depressive symptoms including suicidal ideation in the presence of environmental adversity (Caspi et al., 2003). It has further been pointed out that 5-HTTLPR $\mathrm{x}$ stress interaction depend on age or developmental stage (Lindell et al., 2012). Since neuroplastic mechanisms are involved in the hardwiring of 5-HTTLPR $\mathrm{x}$ environment interactions as mentioned above (Jasinska et al., 2012), genetic variability of $B D N F$ might further be considered as a modifying factor (Grabe et al., 2012; Yu et al., 2012). Accordingly, three-way interactions between $S L C 6 A 4, B D N F$, and environmental adversity have been reported in $\mathrm{S}$ and Met allele carrying children that exhibited the highest risk of depression (Aguilera et al., 2009; Kaufman et al., 2006; Kim, J.M. et al., 2007; Wichers et al., 2008). Although no such effects were found by a recent largescale study (Nederhof et al., 2010a), the same group observed a detrimental epistatic effect of childhood adversity for Met or S allele carriers on effortful control in children (Nederhof et al., 2010b). Effortful control is thought to foster adaptive action by suppression of a dominant response in favor of a more goal-directed behavior and may thereby protect indi- viduals against anxious inhibition and focus on their own distress (Oldehinkel et al., 2011). In terms of cognitive symptoms, healthy BDNF Val/Val and 5HTTLPR S allele carriers developed more rumination while expieriencing stressful life events (Clasen et al., 2011). Moreover, S homozygotes presented reduced cognitive reactivity, a decrease in dysfunctional thinking in the presence of at least one BDNF Met allele (Wells et al., 2010).

Today study results investigating SLC6A4 and $B D N F$ epistasis are rather conclusive on an animal level, but still preliminary on a clinical level. This is not surprising given the tight and complex coupling between SLC6A4, BDNF, and evironmental factors. Hence, inconsistencies with regard to human studies related to $B D N F$ and SLC6A4 epistasis are likely caused by either lacking or varying control of envirnomental factors.

\section{Conclusion}

Over the past decades depression research has made great strides forward resulting in numerous models of its putative underlying neurobiological mechanisms including the monoamine deficiency and neuroplasticity hypothesis (Krishnan \& Nestler, 2010; Kupfer et al., 2012; Wong \& Licinio, 2001). However, its clinical translation is still in its infancy (Berton et al., 2012; Insel, 2012). Major reasons for the encountered difficulties include suboptimal animal models and the purely descriptive operationalization of MDD, which likely comprises various biologically heterogeneous pathological entities (Insel, 2012; Pezawas \& Meyer-Lindenberg, 2010). Nevertheless, neuroimaging studies have been able to identify distinct brain circuitries related to MDD and imaging genetics studies accomplished to trace subtle effects of candidate genes such as SLC6A4 and BDNF on these circuitries (Buckholtz \& Meyer-Lindenberg, 2012; Scharinger et al., 2010). Moreover, substantial efforts have been undertaken by large gene-discovery consortia such as ENIGMA, ADNI, or IMAGEN that provide imaging genetics results collected in large samples (Novak et al., 2012; Potkin et al., 2009; Schumann et al., 2010; Stein et al., 2012; Whelan et al., 2012). In contrast, complex genetic models such as epistasis or haplotype analyses that exhibit larger effect sizes have only been employed in few studies (Cole et al., 2011; Meyer-Lindenberg \& Weinberger, 2006; 
Pezawas et al., 2008; Wang et al., 2012). Thus, future research should facilitate the investigation of epistasis and haplotypes, an approach that is also lacking in current genome-wide association (GWA) imaging genetics studies (Pezawas \& Meyer-Lindenberg, 2010). Therefore, it is not surprising that no converging findings emerged in genome-wide MDD research so far (Demirkan et al., 2011; Sullivan et al., 2009; Wray et al., 2012), which has been quantified by a recent meta-analysis (Major Depressive Disorder Working Group of the Psychiatric GWAS Consortium1, 2012). Biological heterogeneity and low heritability of the MDD phenotype are putative causes, which might have ultimately driven these inconsistencies (Wray et al., 2012). Furthermore, given the acknowledged interaction between environmental adversity and genotype (Caspi et al., 2003), MDD is currently considered as a multifactorial disorder originating from both, environmental as well as genetic factors. So far, study results indicate a substantial influence of SLC6A4 and BDNF on emotion and memory-related brain regions. While emotion regulation seems to provide a direct link to mood disorders, it is less elaborated how structural and functional alterations in memory networks impact on the clinical phenotype of MDD. Clearly, the serotonergic and neurotrophic system impact on neuroplasticity, specifically, in neural domains involved in learning and memory formation. Moreover, both are also fundamental to the adaptation to environmental adversity and are therefore possible components in the etiology of mood disorders. Thus, adressing the complexity of the underlying neurobiology by examining single gene effects, epistasis, and environmental factors in human neuroimaging studies would presumably enrich the clinical value of study results in MDD research. Unfortunately, this comprehensive research strategy adds further sophistication to clinical study designs. Also, it calls for considerably larger sample sizes of neuroimaging studies than typically needed. Epigenetics is another emerging area that promises a better understanding of the translation of environmental factors into molecular signaling pathways that ultimately impact on the development and function of neural circuitries (Badcock \& Crespi, 2008; Houston et al., 2013; Levenson \& Sweatt, 2005; Moore et al., 2013; Puckett \& Lubin, 2011; Skipper, 2011; Sultan \& Day, 2011; Tsankova et al., 2007). However, while significant progress has already been made in animal experiments, results in human neuroimaging studies that clinically validate these findings are still scarce (Wiers, 2012).
Apart from studies that have been able to associate BDNF and SLC6A4 with clinical phenotypes as well as with neural structure and function, both genes have successfully been linked to other 'phenotypes' such as antidepressant drug response and tolerability within pharmacogenomic association studies (Rabl et al., 2010). However, only very few pilot studies have applied an imaging genetics approach to drug treatment studies yet (Rabl et al., 2010). Such a pharmacological imaging genetics strategy utilizing known intermediate imaging phenotypes would foster the neurobiological understanding of antidepressant drug response and tolerability, thereby paving the way for the development of personalized treatments.

Summing up, a vast number of clinical studies demonstrated the impact of SLC6A4 and BDNF on neural circuitries related to MDD in emotion and memory-related networks. Molecular and animal studies have suggested that biological mechanisms are much more complex than originally anticipated, including epistasis and epigenetics. However, the clinical translation and its possible use for diagnostics and treatment have not been carried out yet. Moreover, a brain systems level understanding of antidepressant drug response and its genetic underpinnings is still lacking and should be addressed in future studies. Finally, we suggest the investigation of the specific role of executive networks in the pathobiology of MDD with imaging methods and its genetic determinants. This would not only contribute to a more thorough knowledge of affected neural networks in MDD, but also provide new approaches in the development of new pharmacological and psychotherapeutic strategies in the treatment of MDD.

\section{Acknowledgments}

The authors thank Ulrich Rabl, MD, and Lucie Bartova, MD for proof reading of the manuscript as well as for their helpful comments. This work has been supported by the Austrian Science Fund FWF (KLI148-B00).

\section{References}

Adolphs, R., Tranel, D., Damasio, H. \& Damasio, A. (1994). Impaired recognition of emotion in facial expressions following bilateral damage to the human amygdala. Nature, 372(6507), 669-672. 
Adolphs, R., Tranel, D., Damasio, H. \& Damasio, A.R. (1995). Fear and the human amygdala. $J$ Neurosci, 15(9), 5879-5891.

Aguilera, M., Arias, B., Wichers, M., Barrantes-Vidal, N., Moya, J., Villa, H., van Os, J., Ibanez, M.I., Ruiperez, M.A., Ortet, G. \& Fananas, L. (2009). Early adversity and 5-HTT/BDNF genes: New evidence of gene-environment interactions on depressive symptoms in a general population. Psychol Med, 39(9), 14251432 .

Alasaari, J.S., Lagus, M., Ollila, H.M., Toivola, A., Kivimaki, M., Vahtera, J., Kronholm, E., Harma, M., Puttonen, S. \& Paunio, T. (2012). Environmental stress affects DNA methylation of a $\mathrm{CpG}$ rich promoter region of serotonin transporter gene in a nurse cohort. PLoS One, 7(9), e45813.

Albert, P.R., Le Francois, B. \& Millar, A.M. (2011). Transcriptional dysregulation of 5-HT1A autoreceptors in mental illness. Mol Brain, 4, 21.

Anand, A., Li, Y., Wang, Y., Wu, J., Gao, S., Bukhari, L., Mathews, V.P., Kalnin, A. \& Lowe, M.J. (2005). Activity and connectivity of brain mood regulating circuit in depression: A functional magnetic resonance study. Biol Psychiatry, 57(10), 1079-1088.

Anderson, I.M., Juhasz, G., Thomas, E., Downey, D., McKie, S., Deakin, J.F. \& Elliott, R. (2011). The effect of acute citalopram on face emotion processing in remitted depression: A pharmacoMRI study. Eur Neuropsychopharmacol, 21(1), 140-148.

Ansorge, M.S., Zhou, M., Lira, A., Hen, R. \& Gingrich, J.A. (2004). Early-life blockade of the 5-HT transporter alters emotional behavior in adult mice. Science, 306(5697), 879-881.

American Psychiatric Association. (2000). Diagnostic and Statistical Manual of mental disorders (DSM-IV-TR). Washington, DC: American Psychiatric Association.

American Psychiatric Association. (2010). Practice guidelines for treatment of patients with major depressive disorder (3rd ed.). Washington, DC: American Psychiatric Association.

Arce, E., Simmons, A.N., Lovero, K.L., Stein, M.B. \& Paulus, M.P. (2008). Escitalopram effects on insula and amygdala BOLD activation during emotional processing. Psychopharmacology, 196(4), 661-672.

Autry, A.E. \& Monteggia, L.M. (2012). Brain-Derived Neurotrophic Factor and Neuropsychiatric Disorders. Pharmacol Rev, 64(2), 238-258.

Badcock, C. \& Crespi, B. (2008). Battle of the sexes may set the brain. Nature, 454(7208), 1054-1055.

Banerjee, P., Mehta, M. \& Kanjilal, B. (2007). The 5-HT1A Receptor: A signaling hub linked to emotional balance. In A. Chattopadhyay (Ed.), Serotonin Receptors in Neurobiology. Boca Raton (FL).

Barco, A., Patterson, S.L., Alarcon, J.M., Gromova, P., Mata-Roig, M., Morozov, A. \& Kandel, E.R. (2005). Gene expression profiling of facilitated L-LTP in VP16-CREB mice reveals that BDNF is critical for the maintenance of LTP and its synaptic capture. Neuron, 48(1), 123-137.

Barnes, N.M. \& Sharp, T. (1999). A review of central 5-HT receptors and their function. Neuropharmacology, 38(8), 1083-1152.

Bartova, L., Berger, A. \& Pezawas, L. (2010). Is there a personalized medicine for mood disorders? Eur Arch Psychiatry Clin Neurosci, 260(Suppl 2), S121-126.
Berton, O., Hahn, C.G. \& Thase, M.E. (2012). Are we getting closer to valid translational models for major depression? Science, 338(6103), 75-79.

Bevilacqua, L. \& Goldman, D. (2011). Genetics of emotion. Trends Cogn Sci, 15(9), 401-408.

Bigos, K.L., Pollock, B.G., Aizenstein, H.J., Fisher, P.M., Bies, R.R. \& Hariri, A.R. (2008). Acute 5-HT reuptake blockade potentiates human amygdala reactivity. Neuropsychopharmacology, 33(13), 3221-3225

Bigos, K.L. \& Weinberger, D.R. (2010). Imaging genetics-days of future past. NeuroImage, 53(3), 804-809.

Blier, P. \& Ward, N.M. (2003). Is there a role for 5-HT1A agonists in the treatment of depression? Biol Psychiatry, 53(3), 193-203.

Bocchio-Chiavetto, L., Bagnardi, V., Zanardini, R., Molteni, R., Nielsen, M.G., Placentino, A., Giovannini, C., Rillosi, L., Ventriglia, M., Riva, M.A. \& Gennarelli, M. (2010). Serum and plasma BDNF levels in major depression: A replication study and meta-analyses. World J Biol Psychiatry, 11(6), 763-773.

Boes, A.D., McCormick, L.M., Coryell, W.H. \& Nopoulos, P. (2008). Rostral anterior cingulate cortex volume correlates with depressed mood in normal healthy children. Biol Psychiatry, 63(4), 391-397.

Bonnin, A., Goeden, N., Chen, K., Wilson, M.L., King, J., Shih, J.C., Blakely, R.D., Deneris, E.S. \& Levitt, P. (2011). A transient placental source of serotonin for the fetal forebrain. Nature, 472(7343), 347-350.

Bora, E., Fornito, A., Pantelis, C. \& Yucel, M. (2012). Gray matter abnormalities in Major Depressive Disorder: A meta-analysis of voxel based morphometry studies. J Affect Disord, 138(1-2), $9-18$

Bortolozzi, A., Castane, A., Semakova, J., Santana, N., Alvarado, G., Cortes, R., Ferres-Coy, A., Fernandez, G., Carmona, M.C., Toth, M., Perales, J.C., Montefeltro, A. \& Artigas, F. (2012). Selective siRNA-mediated suppression of 5-HT1A autoreceptors evokes strong anti-depressant-like effects. Mol Psychiatry, $17(6), 612-623$

Bose, S.K., Mehta, M.A., Selvaraj, S., Howes, O.D., Hinz, R., Rabiner, E.A., Grasby, P.M., Turkheimer, F.E. \& Murthy, V. (2011). Presynaptic 5-HT1A is related to 5-HTT receptor density in the human brain. Neuropsychopharmacology, 36(11), 2258-2265.

Bremner, J.D., Narayan, M., Anderson, E.R., Staib, L.H., Miller, H.L. \& Charney, D.S. (2000). Hippocampal volume reduction in major depression. Am J Psychiatry, 157(1), 115-118.

Browning, M., Holmes, E.A. \& Harmer, C.J. (2010). The modification of attentional bias to emotional information: A review of the techniques, mechanisms, and relevance to emotional disorders. Cogn Affect Behav Neurosci, 10(1), 8-20.

Browning, M., Reid, C., Cowen, P.J., Goodwin, G.M. \& Harmer, C.J. (2007). A single dose of citalopram increases fear recognition in healthy subjects. J Psychopharmacol, 21(7), 684-690.

Brunoni, A.R., Lopes, M. \& Fregni, F. (2008). A systematic review and meta-analysis of clinical studies on major depression and BDNF levels: Implications for the role of neuroplasticity in depression. Int J Neuropsychopharmacol, 11(8), 11691180 . 
Buckholtz, J.W. \& Meyer-Lindenberg, A. (2012). Psychopathology and the human connectome: Toward a transdiagnostic model of risk for mental illness. Neuron, 74(6), 990-1004.

Burghardt, N.S., Bush, D.E., McEwen, B.S. \& LeDoux, J.E. (2007). Acute selective serotonin reuptake inhibitors increase conditioned fear expression: Blockade with a 5-HT(2C) receptor antagonist. Biol Psychiatry, 62(10), 1111-1118.

Campbell, S. \& Macqueen, G. (2004). The role of the hippocampus in the pathophysiology of major depression. J Psychiatry Neurosci, 29(6), 417-426.

Canli, T. \& Lesch, K.P. (2007). Long story short: The serotonin transporter in emotion regulation and social cognition. Nat Neurosci, 10(9), 1103-1109.

Canli, T., Omura, K., Haas, B.W., Fallgatter, A., Constable, R.T. \& Lesch, K.P. (2005). Beyond affect: A role for genetic variation of the serotonin transporter in neural activation during a cognitive attention task. Proc Natl Acad Sci U S A, 102(34), 12224-12229.

Canli, T., Qiu, M., Omura, K., Congdon, E., Haas, B.W., Amin, Z., Herrmann, M.J., Constable, R.T. \& Lesch, K.P. (2006). Neural correlates of epigenesis. Proc Natl Acad Sci U S A, 103(43), 16033-16038.

Caspi, A., Hariri, A.R., Holmes, A., Uher, R. \& Moffitt, T.E. (2010). Genetic sensitivity to the environment: The case of the serotonin transporter gene and its implications for studying complex diseases and traits. Am J Psychiatry, 167(5), 509-527.

Caspi, A., Sugden, K., Moffitt, T.E., Taylor, A., Craig, I.W., Harrington, H., McClay, J., Mill, J., Martin, J., Braithwaite, A. \& Poulton, R. (2003). Influence of life stress on depression: Moderation by a polymorphism in the 5-HTT gene. Science, 301(5631), 386-389.

Castren, E. (2005). Is mood chemistry? Nat Rev Neurosci, 6(3), 241246.

Castren, E. \& Rantamaki, T. (2010). The role of BDNF and its receptors in depression and antidepressant drug action: Reactivation of developmental plasticity. Dev Neurobiol, 70(5), 289-297.

Cathomas, F., Vogler, C., Euler-Sigmund, J.C., de Quervain, D.J. \& Papassotiropoulos, A. (2010). Fine-mapping of the brain-derived neurotrophic factor (BDNF) gene supports an association of the Val66Met polymorphism with episodic memory. Int J Neuropsychopharmacol, 13(8), 975-980

Chen, C.H., Suckling, J., Ooi, C., Fu, C.H., Williams, S.C., Walsh, N.D., Mitterschiffthaler, M.T., Pich, E.M. \& Bullmore, E. (2008). Functional coupling of the amygdala in depressed patients treated with antidepressant medication. Neuropsychopharmacology, 33(8), 1909-1918.

Chen, Z.Y., Jing, D., Bath, K.G., Ieraci, A., Khan, T., Siao, C.J., Herrera, D.G., Toth, M., Yang, C., McEwen, B.S., Hempstead, B.L. \& Lee, F.S. (2006). Genetic variant BDNF (Val66Met) polymorphism alters anxiety-related behavior. Science, 314(5796), 140-143.

Chen, Z.Y., Patel, P.D., Sant, G., Meng, C.X., Teng, K.K., Hempstead, B.L. \& Lee, F.S. (2004). Variant brain-derived neurotrophic factor (BDNF) (Met66) alters the intracellular trafficking and activity-dependent secretion of wild-type BDNF in neurosecretory cells and cortical neurons. J Neurosci, 24(18), 4401-4411.
Chepenik, L.G., Fredericks, C., Papademetris, X., Spencer, L., Lacadie, C., Wang, F., Pittman, B., Duncan, J.S., Staib, L.H., Duman, R.S., Gelernter, J. \& Blumberg, H.P. (2009). Effects of the brain-derived neurotrophic growth factor val66met variation on hippocampus morphology in bipolar disorder. Neuropsychopharmacology, 34(4), 944-951.

Chiang, M.C., Barysheva, M., Toga, A.W., Medland, S.E., Hansell, N.K., James, M.R., McMahon, K.L., de Zubicaray, G.I., Martin, N.G., Wright, M.J. \& Thompson, P.M. (2011). BDNF gene effects on brain circuitry replicated in 455 twins. NeuroImage, $55(2), 448-454$.

Clasen, P.C., Wells, T.T., Knopik, V.S., McGeary, J.E. \& Beevers, C.G. (2011). 5-HTTLPR and BDNF Val66Met polymorphisms moderate effects of stress on rumination. Genes Brain Behav, 10(7), 740-746.

Cole, J., Weinberger, D.R., Mattay, V.S., Cheng, X., Toga, A.W., Thompson, P.M., Powell-Smith, G., Cohen-Woods, S., Simmons, A., McGuffin, P. \& Fu, C.H. (2011). No effect of 5HTTLPR or BDNF Val66Met polymorphism on hippocampal morphology in major depression. Genes Brain Behav, 10(7), 756-764.

Colla, M., Kronenberg, G., Deuschle, M., Meichel, K., Hagen, T., Bohrer, M. \& Heuser, I. (2007). Hippocampal volume reduction and HPA-system activity in major depression. J Psychiatr Res, 41(7), 553-560.

Cordell, H.J. (2002). Epistasis: What it means, what it doesn't mean, and statistical methods to detect it in humans. Hum Mol Genet, 11(20), 2463-2468.

Cotter, D., Mackay, D., Landau, S., Kerwin, R. \& Everall, I. (2001). Reduced glial cell density and neuronal size in the anterior cingulate cortex in major depressive disorder. Arch Gen Psychiatry, $58(6), 545-553$.

Cremers, H.R., Demenescu, L.R., Aleman, A., Renken, R., van Tol, M.J., van der Wee, N.J., Veltman, D.J. \& Roelofs, K. (2010). Neuroticism modulates amygdala-prefrontal connectivity in response to negative emotional facial expressions. NeuroImage, 49(1), 963-970.

Crescentini, C., Seyed-Allaei, S., Vallesi, A. \& Shallice, T. (2012). Two networks involved in producing and realizing plans. Neuropsychologia, 50(7), 1521-1535.

Davidson, J.R. (2010). Major depressive disorder treatment guidelines in America and Europe. J Clin Psychiatry, 71, Suppl E1, e04.

Davis, M. \& Whalen, P.J. (2001). The amygdala: Vigilance and emotion. Mol Psychiatry, 6(1), 13-34.

de Kloet, E.R., Joels, M. \& Holsboer, F. (2005). Stress and the brain: From adaptation to disease. Nat Rev Neurosci, 6(6), 463-475.

Del-Ben, C.M., Deakin, J.F., McKie, S., Delvai, N.A., Williams, S.R., Elliott, R., Dolan, M. \& Anderson, I.M. (2005). The effect of citalopram pretreatment on neuronal responses to neuropsychological tasks in normal volunteers: An FMRI study. Neuropsychopharmacology, 30(9), 1724-1734.

Delgado, P.L. (2000). Depression: The case for a monoamine deficiency. J Clin Psychiatry, 61 Suppl 6, 7-11.

Demirkan, A., Penninx, B.W., Hek, K., Wray, N.R., Amin, N., Aulchenko, Y.S., van Dyck, R., de Geus, E.J., Hofman, A., Uitterlinden, A.G., Hottenga, J.J., Nolen, W.A., Oostra, B.A., 
Sullivan, P.F., Willemsen, G., Zitman, F.G., Tiemeier, H., Janssens, A.C., Boomsma, D.I., van Duijn, C.M. \& Middeldorp, C.M. (2011). Genetic risk profiles for depression and anxiety in adult and elderly cohorts. Mol Psychiatry, 16(7), 773-783.

Dempster, E., Toulopoulou, T., McDonald, C., Bramon, E., Walshe, M., Filbey, F., Wickham, H., Sham, P.C., Murray, R.M. \& Collier, D.A. (2005). Association between BDNF val66 met genotype and episodic memory. Am J Med Genet B Neuropsychiatr Genet, 134B(1), 73-75.

DeRubeis, R.J., Siegle, G.J. \& Hollon, S.D. (2008). Cognitive therapy versus medication for depression: Treatment outcomes and neural mechanisms. Nat Rev Neurosci, 9(10), 788-796.

Dhasmana, K.M., Zhu, Y.N., Cruz, S.L. \& Villalon, C.M. (1993). Gastrointestinal effects of 5-hydroxytryptamine and related drugs. Life Sci, 53(22), 1651-1661.

Disner, S.G., Beevers, C.G., Haigh, E.A. \& Beck, A.T. (2011). Neural mechanisms of the cognitive model of depression. Nat Rev Neurosci, 12(8), 467-477.

Dooley, A.E., Pappas, I.S. \& Parnavelas, J.G. (1997). Serotonin promotes the survival of cortical glutamatergic neurons in vitro. Exp Neurol, 148(1), 205-214.

Dougherty, L.R., Klein, D.N., Congdon, E., Canli, T. \& Hayden, E.P. (2010). Interaction between 5-HTTLPR and BDNF Val66Met polymorphisms on HPA axis reactivity in preschoolers. Biol Psychol, 83(2), 93-100.

Drabant, E.M., Ramel, W., Edge, M.D., Hyde, L.W., Kuo, J.R., Goldin, P.R., Hariri, A.R. \& Gross, J.J. (2012). Neural mechanisms underlying 5-HTTLPR-related sensitivity to acute stress. Am J Psychiatry, 169(4), 397-405.

Dreimuller, N., Schlicht, K.F., Wagner, S., Peetz, D., Borysenko, L., Hiemke, C., Lieb, K. \& Tadic, A. (2012). Early reactions of brain-derived neurotrophic factor in plasma (pBDNF) and outcome to acute antidepressant treatment in patients with Major Depression. Neuropharmacology, 62(1), 264-269.

Drevets, W.C. (2003). Neuroimaging abnormalities in the amygdala in mood disorders. Ann N Y Acad Sci, 985, 420-444.

Drevets, W.C., Price, J.L. \& Furey, M.L. (2008a). Brain structural and functional abnormalities in mood disorders: Implications for neurocircuitry models of depression. Brain Struct Funct, 213(1-2), 93-118.

Drevets, W.C., Price, J.L., Simpson, J.R., Jr., Todd, R.D., Reich, T., Vannier, M. \& Raichle, M.E. (1997). Subgenual prefrontal cortex abnormalities in mood disorders. Nature, 386(6627), 824-827.

Drevets, W.C., Savitz, J. \& Trimble, M. (2008b). The subgenual anterior cingulate cortex in mood disorders. CNS Spectr, 13(8), 663-681.

Duman, R.S. \& Aghajanian, G.K. (2012). Synaptic dysfunction in depression: Potential therapeutic targets. Science, 338(6103), 68-72.

Duman, R.S., Malberg, J., Nakagawa, S. \& D’Sa, C. (2000). Neuronal Plasticity and Survival in Mood Disorders. Biol Psychiatry, 48(8), 732-739.

Duman, R.S. \& Monteggia, L.M. (2006). A neurotrophic model for stress-related mood disorders. Biol Psychiatry, 59(12), 11161127.
Egan, M.F., Kojima, M., Callicott, J.H., Goldberg, T.E., Kolachana, B.S., Bertolino, A., Zaitsev, E., Gold, B., Goldman, D., Dean, M., Lu, B. \& Weinberger, D.R. (2003). The BDNF val66met polymorphism affects activity-dependent secretion of BDNF and human memory and hippocampal function. Cell, 112(2), 257-269.

Eisch, A.J. \& Petrik, D. (2012). Depression and hippocampal neurogenesis: A road to remission? Science, 338(6103), 72-75.

Eker, C., Kitis, O., Taneli, F., Eker, O.D., Ozan, E., Yucel, K., Coburn, K. \& Gonul, A.S. (2010). Correlation of serum BDNF levels with hippocampal volumes in first episode, medication-free depressed patients. Eur Arch Psychiatry Clin Neurosci, 260(7), 527-533.

Eley, T.C., Sugden, K., Corsico, A., Gregory, A.M., Sham, P., McGuffin, P., Plomin, R. \& Craig, I.W. (2004). Geneenvironment interaction analysis of serotonin system markers with adolescent depression. Mol Psychiatry, 9(10), 908915 .

Ernst, C., Marshall, C.R., Shen, Y., Metcalfe, K., Rosenfeld, J., Hodge, J.C., Torres, A., Blumenthal, I., Chiang, C., Pillalamarri, V., Crapper, L., Diallo, A.B., Ruderfer, D., Pereira, S., Sklar, P., Purcell, S., Wildin, R.S., Spencer, A.C., Quade, B.F., Harris, D.J., Lemyre, E., Wu, B.L., Stavropoulos, D.J., Geraghty, M.T., Shaffer, L.G., Morton, C.C., Scherer, S.W., Gusella, J.F. \& Talkowski, M.E. (2012). Highly Penetrant Alterations of a Critical Region Including BDNF in Human Psychopathology and Obesity. Arch Gen Psychiatry, 1-9.

Everaert, J., Koster, E.H. \& Derakshan, N. (2012). The combined cognitive bias hypothesis in depression. Clin Psychol Rev, 32(5), 413-424.

Evers, E.A., Tillie, D.E., van der Veen, F.M., Lieben, C.K., Jolles, J., Deutz, N.E. \& Schmitt, J.A. (2005). Effects of a novel method of acute tryptophan depletion on plasma tryptophan and cognitive performance in healthy volunteers. Psychopharmacology, 178(1), 92-99.

Fales, C.L., Barch, D.M., Rundle, M.M., Mintun, M.A., Mathews, J., Snyder, A.Z. \& Sheline, Y.I. (2009). Antidepressant treatment normalizes hypoactivity in dorsolateral prefrontal cortex during emotional interference processing in major depression. $J$ Affect Disord, 112(1-3), 206-211.

Feder, A., Skipper, J., Blair, J.R., Buchholz, K., Mathew, S.J., Schwarz, M., Doucette, J.T., Alonso, A., Collins, K.A., Neumeister, A. \& Charney, D.S. (2011). Tryptophan depletion and emotional processing in healthy volunteers at high risk for depression. Biol Psychiatry, 69(8), 804-807.

Fell, J. \& Axmacher, N. (2011). The role of phase synchronization in memory processes. Nat Rev Neurosci, 12(2), 105-118.

Finger, E.C., Marsh, A.A., Buzas, B., Kamel, N., Rhodes, R., Vythilingham, M., Pine, D.S., Goldman, D. \& Blair, J.R. (2007). The impact of tryptophan depletion and 5HTTLPR genotype on passive avoidance and response reversal instrumental learning tasks. Neuropsychopharmacology, 32(1), 206-215.

Firk, C., Siep, N. \& Markus, C.R. (2012). Serotonin transporter genotype modulates cognitive reappraisal of negative emotions: A functional magnetic resonance imaging study. Soc Cogn Affect Neurosci, [Epub ahead of print]. 
Flint, J. \& Munafo, M.R. (2007). The endophenotype concept in psychiatric genetics. Psychol Med, 37(2), 163-180.

Foland-Ross, L.C. \& Gotlib, I.H. (2012). Cognitive and neural aspects of information processing in major depressive disorder: An integrative perspective. Front Psychol, 3, 489.

Frodl, T., Koutsouleris, N., Bottlender, R., Born, C., Jager, M., Morgenthaler, M., Scheuerecker, J., Zill, P., Baghai, T., Schule, C., Rupprecht, R., Bondy, B., Reiser, M., Moller, H.J. \& Meisenzahl, E.M. (2008a). Reduced gray matter brain volumes are associated with variants of the serotonin transporter gene in major depression. Mol Psychiatry, 13(12), 1093-1101.

Frodl, T., Meisenzahl, E.M., Zill, P., Baghai, T., Rujescu, D., Leinsinger, G., Bottlender, R., Schule, C., Zwanzger, P., Engel, R.R., Rupprecht, R., Bondy, B., Reiser, M. \& Moller, H.J. (2004). Reduced hippocampal volumes associated with the long variant of the serotonin transporter polymorphism in major depression. Arch Gen Psychiatry, 61(2), 177-183.

Frodl, T., Reinhold, E., Koutsouleris, N., Donohoe, G., Bondy, B., Reiser, M., Moller, H.J. \& Meisenzahl, E.M. (2010). Childhood stress, serotonin transporter gene and brain structures in major depression. Neuropsychopharmacology, 35(6), 1383-1390.

Frodl, T., Schaub, A., Banac, S., Charypar, M., Jager, M., Kummler, P., Bottlender, R., Zetzsche, T., Born, C., Leinsinger, G., Reiser, M., Moller, H.J. \& Meisenzahl, E.M. (2006). Reduced hippocampal volume correlates with executive dysfunctioning in major depression. J Psychiatry Neurosci, 31(5), 316-323.

Frodl, T., Schule, C., Schmitt, G., Born, C., Baghai, T., Zill, P., Bottlender, R., Rupprecht, R., Bondy, B., Reiser, M., Moller, H.J. \& Meisenzahl, E.M. (2007). Association of the brain-derived neurotrophic factor Val66Met polymorphism with reduced hippocampal volumes in major depression. Arch Gen Psychiatry, 64(4), 410-416.

Frodl, T., Zill, P., Baghai, T., Schule, C., Rupprecht, R., Zetzsche, T., Bondy, B., Reiser, M., Moller, H.J. \& Meisenzahl, E.M. (2008b). Reduced hippocampal volumes associated with the long variant of the tri- and diallelic serotonin transporter polymorphism in major depression. Am J Med Genet B Neuropsychiatr Genet, 147B(7), 1003-1007.

Fuster, J.M. (2001). The prefrontal cortex-an update: Time is of the essence. Neuron, 30(2), 319-333.

Gasic, G.P., Smoller, J.W., Perlis, R.H., Sun, M., Lee, S., Kim, B.W., Lee, M.J., Holt, D.J., Blood, A.J., Makris, N., Kennedy, D.K., Hoge, R.D., Calhoun, J., Fava, M., Gusella, J.F. \& Breiter, H.C. (2009). BDNF, relative preference, and reward circuitry responses to emotional communication. Am J Med Genet B Neuropsychiatr Genet, 150B(6), 762-781.

Gaspar, P., Cases, O. \& Maroteaux, L. (2003). The developmental role of serotonin: News from mouse molecular genetics. Nat Rev Neurosci, 4(12), 1002-1012.

Gatt, J.M., Nemeroff, C.B., Dobson-Stone, C., Paul, R.H., Bryant, R.A., Schofield, P.R., Gordon, E., Kemp, A.H. \& Williams, L.M. (2009). Interactions between BDNF Val66Met polymorphism and early life stress predict brain and arousal pathways to syndromal depression and anxiety. Mol Psychiatry, 14(7), 681-695.

Gelenberg, A.J. (2010). A review of the current guidelines for depression treatment. J Clin Psychiatry, 71(7), e15.
Gerritsen, L., Tendolkar, I., Franke, B., Vasquez, A.A., Kooijman, S., Buitelaar, J., Fernandez, G. \& Rijpkema, M. (2012). BDNF Val66Met genotype modulates the effect of childhood adversity on subgenual anterior cingulate cortex volume in healthy subjects. Mol Psychiatry, 17(6), 597-603.

Goldberg, T.E., Iudicello, J., Russo, C., Elvevag, B., Straub, R., Egan, M.F. \& Weinberger, D.R. (2008). BDNF Val66Met polymorphism significantly affects d' in verbal recognition memory at short and long delays. Biol Psychol, 77(1), 20-24.

Goldman-Rakic, P. (1997). Neurobiology. Space and time in the mental universe. Nature, 386(6625), 559-560.

Goldman, D., Oroszi, G. \& Ducci, F. (2005). The genetics of addictions: Uncovering the genes. Nat Rev Genet, 6(7), 521-532.

Goldstein, K.E., Hazlett, E.A., Savage, K.R., Berlin, H.A., Hamilton, H.K., Zelmanova, Y., Look, A.E., Koenigsberg, H.W., Mitsis, E.M., Tang, C.Y., McNamara, M., Siever, L.J., Cohen, B.H. $\&$ New, A.S. (2011). Dorso- and ventro-lateral prefrontal volume and spatial working memory in schizotypal personality disorder. Behav Brain Res, 218(2), 335-340.

Goodyer, I.M., Croudace, T., Dudbridge, F., Ban, M. \& Herbert, J. (2010). Polymorphisms in BDNF (Val66Met) and 5-HTTLPR, morning cortisol and subsequent depression in at-risk adolescents. Br J Psychiatry, 197(5), 365-371.

Grabe, H.J., Schwahn, C., Mahler, J., Appel, K., Schulz, A., Spitzer, C., Fenske, K., Barnow, S., Freyberger, H.J., Teumer, A., Petersmann, A., Biffar, R., Rosskopf, D., John, U. \& Volzke, H. (2012). Genetic epistasis between the brainderived neurotrophic factor Val66Met polymorphism and the 5-HTT promoter polymorphism moderates the susceptibility to depressive disorders after childhood abuse. Prog Neuropsychopharmacol Biol Psychiatry, 36(2), 264-270.

Gross, C. \& Hen, R. (2004). The developmental origins of anxiety. Nat Rev Neurosci, 5(7), 545-552.

Groves, J.O. (2007). Is it time to reassess the BDNF hypothesis of depression? Mol Psychiatry, 12(12), 1079-1088.

Haas, B.W., Omura, K., Constable, R.T. \& Canli, T. (2007). Emotional conflict and neuroticism: Personality-dependent activation in the amygdala and subgenual anterior cingulate. Behav Neurosci, 121(2), 249-256.

Haddad, A.D., Williams, J.M., McTavish, S.F. \& Harmer, C.J. (2009). Low-dose tryptophan depletion in recovered depressed women induces impairments in autobiographical memory specificity. Psychopharmacology (Berl), 207(3), 499-508.

Hajek, T., Kopecek, M. \& Hoschl, C. (2012). Reduced hippocampal volumes in healthy carriers of brain-derived neurotrophic factor Val66Met polymorphism: Meta-analysis. World J Biol Psychiatry, 13(3), 178-187.

Hajek, T., Kozeny, J., Kopecek, M., Alda, M. \& Hoschl, C. (2008). Reduced subgenual cingulate volumes in mood disorders: A meta-analysis. J Psychiatry Neurosci, 33(2), 91-99.

Hamilton, J.P., Siemer, M. \& Gotlib, I.H. (2008). Amygdala volume in major depressive disorder: A meta-analysis of magnetic resonance imaging studies. Mol Psychiatry, 13(11), 9931000.

Hansell, N.K., James, M.R., Duffy, D.L., Birley, A.J., Luciano, M., Geffen, G.M., Wright, M.J., Montgomery, G.W. \& Martin, N.G. (2007). Effect of the BDNF V166M polymorphism on working 
memory in healthy adolescents. Genes Brain Behav, 6(3), 260268.

Hariri, A.R., Goldberg, T.E., Mattay, V.S., Kolachana, B.S., Callicott, J.H., Egan, M.F. \& Weinberger, D.R. (2003a). Brainderived neurotrophic factor val66met polymorphism affects human memory-related hippocampal activity and predicts memory performance. J Neurosci, 23(17), 6690-6694.

Hariri, A.R., Mattay, V.S., Tessitore, A., Fera, F. \& Weinberger, D.R. (2003b). Neocortical modulation of the amygdala response to fearful stimuli. Biol Psychiatry, 53(6), 494-501.

Hariri, A.R., Mattay, V.S., Tessitore, A., Kolachana, B., Fera, F., Goldman, D., Egan, M.F. \& Weinberger, D.R. (2002). Serotonin transporter genetic variation and the response of the human amygdala. Science, 297(5580), 400-403.

Harmer, C.J., Mackay, C.E., Reid, C.B., Cowen, P.J. \& Goodwin, G.M. (2006). Antidepressant drug treatment modifies the neural processing of nonconscious threat cues. Biol Psychiatry, 59(9), 816-820.

Hashimoto, K. (2010). Brain-derived neurotrophic factor as a biomarker for mood disorders: An historical overview and future directions. Psychiatry Clin Neurosci, 64(4), 341-357.

Hashimoto, R., Moriguchi, Y., Yamashita, F., Mori, T., Nemoto, K., Okada, T., Hori, H., Noguchi, H., Kunugi, H. \& Ohnishi, T. (2008). Dose-dependent effect of the Val66Met polymorphism of the brain-derived neurotrophic factor gene on memoryrelated hippocampal activity. Neurosci Res, 61(4), 360367.

Hawrylycz, M.J., Lein, E.S., Guillozet-Bongaarts, A.L., Shen, E.H., Ng, L., Miller, J.A., van de Lagemaat, L.N., Smith, K.A., Ebbert, A., Riley, Z.L., Abajian, C., Beckmann, C.F., Bernard, A., Bertagnolli, D., Boe, A.F., Cartagena, P.M., Chakravarty, M.M., Chapin, M., Chong, J., Dalley, R.A., Daly, B.D., Dang, C., Datta, S., Dee, N., Dolbeare, T.A., Faber, V., Feng, D., Fowler, D.R., Goldy, J., Gregor, B.W., Haradon, Z., Haynor, D.R., Hohmann, J.G., Horvath, S., Howard, R.E., Jeromin, A., Jochim, J.M., Kinnunen, M., Lau, C., Lazarz, E.T., Lee, C., Lemon, T.A., Li, L., Li, Y., Morris, J.A., Overly, C.C., Parker, P.D., Parry, S.E., Reding, M., Royall, J.J., Schulkin, J., Sequeira, P.A., Slaughterbeck, C.R., Smith, S.C., Sodt, A.J., Sunkin, S.M., Swanson, B.E., Vawter, M.P., Williams, D., Wohnoutka, P., Zielke, H.R., Geschwind, D.H., Hof, P.R., Smith, S.M., Koch, C., Grant, S.G. \& Jones, A.R. (2012). An anatomically comprehensive atlas of the adult human brain transcriptome. Nature, 489(7416), 391-399.

Hayden, B.Y., Pearson, J.M. \& Platt, M.L. (2009). Fictive reward signals in the anterior cingulate cortex. Science, 324(5929), 948-950.

Heinz, A., Braus, D.F., Smolka, M.N., Wrase, J., Puls, I., Hermann, D., Klein, S., Grusser, S.M., Flor, H., Schumann, G., Mann, K. \& Buchel, C. (2005). Amygdala-prefrontal coupling depends on a genetic variation of the serotonin transporter. Nat Neurosci, $8(1), 20-21$.

Heldt, S.A., Stanek, L., Chhatwal, J.P. \& Ressler, K.J. (2007). Hippocampus-specific deletion of BDNF in adult mice impairs spatial memory and extinction of aversive memories. Mol Psychiatry, 12(7), 656-670.

Hetrick, S., Merry, S., McKenzie, J., Sindahl, P. \& Proctor, M. (2007). Selective serotonin reuptake inhibitors (SSRIs) for depressive disorders in children and adolescents. Cochrane Database Syst $\operatorname{Rev}(3), \mathrm{CD} 004851$.

Hindi Attar, C., Finckh, B. \& Buchel, C. (2012). The influence of serotonin on fear learning. PLoS One, 7(8), e42397.

Hirschfeld, R.M. (2000). History and evolution of the monoamine hypothesis of depression. J Clin Psychiatry, 61 Suppl 6, 4-6.

Ho, B.C., Milev, P., O’Leary, D.S., Librant, A., Andreasen, N.C. \& Wassink, T.H. (2006). Cognitive and magnetic resonance imaging brain morphometric correlates of brain-derived neurotrophic factor Val66Met gene polymorphism in patients with schizophrenia and healthy volunteers. Arch Gen Psychiatry, 63(7), 731-740

Holtzheimer, P.E., Kelley, M.E., Gross, R.E., Filkowski, M.M., Garlow, S.J., Barrocas, A., Wint, D., Craighead, M.C., Kozarsky, J., Chismar, R., Moreines, J.L., Mewes, K., Posse, P.R., Gutman, D.A. \& Mayberg, H.S. (2012). Subcallosal cingulate deep brain stimulation for treatment-resistant unipolar and bipolar depression. Arch Gen Psychiatry, 69(2), 150-158.

Homberg, J.R. \& Lesch, K.P. (2011). Looking on the bright side of serotonin transporter gene variation. Bioll Psychiatry, 69(6), 513-519.

Houston, I., Peter, C.J., Mitchell, A., Straubhaar, J., Rogaev, E. \& Akbarian, S. (2013). Epigenetics in the human brain. Neuropsychopharmacology, 38(1), 183-197.

Hoyer, D., Hannon, J.P. \& Martin, G.R. (2002). Molecular, pharmacological and functional diversity of 5-HT receptors. Pharmacol Biochem Behav, 71(4), 533-554.

Hranilovic, D., Lesch, K.P., Ugarkovic, D., Cicin-Sain, L. \& Jernej, B. (1996). Identification of serotonin transporter mRNA in rat platelets. J Neural Transm, 103(8-9), 957-965.

Hu, Y. \& Russek, S.J. (2008). BDNF and the diseased nervous system: A delicate balance between adaptive and pathological processes of gene regulation. J Neurochem, 105(1), 1-17.

Insel, T.R. (2012). Next-generation treatments for mental disorders. Sci Transl Med, 4(155), 155ps119.

Jang, J.H., Yun, J.Y., Jung, W.H., Shim, G., Byun, M.S., Hwang, J.Y., Kim, S.N., Choi, C.H. \& Kwon, J.S. (2012). The impact of genetic variation in COMT and BDNF on resting-state functional connectivity. International Journal of Imaging Systems and Technology, 22(1), 97-102.

Jasinska, A.J., Lowry, C.A. \& Burmeister, M. (2012). Serotonin transporter gene, stress and raphe-raphe interactions: A molecular mechanism of depression. Trends Neurosci, 35(7), 395402.

Jedema, H.P., Gianaros, P.J., Greer, P.J., Kerr, D.D., Liu, S., Higley, J.D., Suomi, S.J., Olsen, A.S., Porter, J.N., Lopresti, B.J., Hariri, A.R. \& Bradberry, C.W. (2010). Cognitive impact of genetic variation of the serotonin transporter in primates is associated with differences in brain morphology rather than serotonin neurotransmission. Mol Psychiatry, 15(5), 512-522, 446.

Jessen, F., Schuhmacher, A., von Widdern, O., Guttenthaler, V., Hofels, S., Suliman, H., Scheef, L., Block, W., Urbach, H., Maier, W. \& Zobel, A. (2009). No association of the Val66Met polymorphism of the brain-derived neurotrophic factor with hippocampal volume in major depression. Psychiatr Genet, 19(2), 99-101. 
Joffe, R.T., Gatt, J.M., Kemp, A.H., Grieve, S., Dobson-Stone, C., Kuan, S.A., Schofield, P.R., Gordon, E. \& Williams, L.M. (2009). Brain derived neurotrophic factor Val66Met polymorphism, the five factor model of personality and hippocampal volume: Implications for depressive illness. Hum Brain Mapp, 30(4), 1246-1256.

Jonassen, R., Endestad, T., Neumeister, A., Foss Haug, K.B., Berg, J.P. \& Landro, N.I. (2012). Serotonin transporter polymorphism modulates N-back task performance and fMRI BOLD signal intensity in healthy women. PLoS One, 7(1), e30564.

Jones, J.L., Esber, G.R., McDannald, M.A., Gruber, A.J., Hernandez, A., Mirenzi, A. \& Schoenbaum, G. (2012). Orbitofrontal Cortex Supports Behavior and Learning Using Inferred But Not Cached Values. Science, 338(6109), 4.

Kalbitzer, J., Erritzoe, D., Holst, K.K., Nielsen, F.A., Marner, L., Lehel, S., Arentzen, T., Jernigan, T.L. \& Knudsen, G.M. (2010). Seasonal changes in brain serotonin transporter binding in short serotonin transporter linked polymorphic region-allele carriers but not in long-allele homozygotes. Biol Psychiatry, 67(11), 1033-1039.

Kambeitz, J.P., Bhattacharyya, S., Kambeitz-Ilankovic, L.M., Valli, I., Collier, D.A. \& McGuire, P. (2012). Effect of BDNF val(66)met polymorphism on declarative memory and its neural substrate: A meta-analysis. Neurosci Biobehav Rev, 36(9), 2165-2177.

Kang, H.J., Voleti, B., Hajszan, T., Rajkowska, G., Stockmeier, C.A., Licznerski, P., Lepack, A., Majik, M.S., Jeong, L.S., Banasr, M., Son, H. \& Duman, R.S. (2012). Decreased expression of synapse-related genes and loss of synapses in major depressive disorder. Nat Med, 18(9), 1413-1417.

Kapur, S., Phillips, A.G. \& Insel, T.R. (2012). Why has it taken so long for biological psychiatry to develop clinical tests and what to do about it? Mol Psychiatry, 17(12), 1174-1179.

Karg, K., Burmeister, M., Shedden, K. \& Sen, S. (2011). The serotonin transporter promoter variant (5-HTTLPR), stress, and depression meta-analysis revisited: Evidence of genetic moderation. Arch Gen Psychiatry, 68(5), 444-454.

Karnik, M.S., Wang, L., Barch, D.M., Morris, J.C. \& Csernansky, J.G. (2010). BDNF polymorphism rs6265 and hippocampal structure and memory performance in healthy control subjects. Psychiatry Res, 178(2), 425-429.

Kaufman, J., Yang, B.Z., Douglas-Palumberi, H., Grasso, D., Lipschitz, D., Houshyar, S., Krystal, J.H. \& Gelernter, J. (2006). Brain-derived neurotrophic factor-5-HTTLPR gene interactions and environmental modifiers of depression in children. Biol Psychiatry, 59(8), 673-680.

Kendler, K.S., Kuhn, J. \& Prescott, C.A. (2004). The interrelationship of neuroticism, sex, and stressful life events in the prediction of episodes of major depression. Am J Psychiatry, 161(4), 631-636.

Kim, J.J. \& Diamond, D.M. (2002). The stressed hippocampus, synaptic plasticity and lost memories. Nat Rev Neurosci, 3(6), 453-462.

Kim, J.M., Stewart, R., Kim, S.W., Yang, S.J., Shin, I.S., Kim, Y.H. \& Yoon, J.S. (2007). Interactions between life stressors and susceptibility genes (5-HTTLPR and BDNF) on depression in Korean elders. Biol Psychiatry, 62(5), 423-428.
Kinnally, E.L., Tarara, E.R., Mason, W.A., Mendoza, S.P., Abel, K., Lyons, L.A. \& Capitanio, J.P. (2010). Serotonin transporter expression is predicted by early life stress and is associated with disinhibited behavior in infant rhesus macaques. Genes Brain Behav, 9(1), 45-52.

Kiyasova, V. \& Gaspar, P. (2011). Development of raphe serotonin neurons from specification to guidance. Eur J Neurosci, 34(10), 1553-1562.

Klomp, A., Tremoleda, J.L., Schrantee, A., Gsell, W. \& Reneman, L. (2012). The use of pharmacological-challenge fMRI in preclinical research: Application to the 5-HT system. $J$ Vis Exp (62), e3956.

Koenigs, M. \& Grafman, J. (2009). The functional neuroanatomy of depression: Distinct roles for ventromedial and dorsolateral prefrontal cortex. Behav Brain Res, 201(2), 239-243.

Koolschijn, P.C., van Haren, N.E., Bakker, S.C., Hoogendoorn, M.L., Hulshoff Pol, H.E. \& Kahn, R.S. (2010). Effects of brain-derived neurotrophic factor Val66Met polymorphism on hippocampal volume change in schizophrenia. Hippocampus, 20(9), 1010-1017.

Kozisek, M.E., Middlemas, D. \& Bylund, D.B. (2008). Brainderived neurotrophic factor and its receptor tropomyosinrelated kinase $\mathrm{B}$ in the mechanism of action of antidepressant therapies. Pharmacol Ther, 117(1), 30-51.

Kranz, G.S., Kasper, S. \& Lanzenberger, R. (2010). Reward and the serotonergic system. Neuroscience, 166(4), 1023-1035.

Kringelbach, M.L. (2005). The human orbitofrontal cortex: Linking reward to hedonic experience. Nat Rev Neurosci, 6(9), 691-702.

Kringelbach, M.L. \& Rolls, E.T. (2004). The functional neuroanatomy of the human orbitofrontal cortex: Evidence from neuroimaging and neuropsychology. Prog Neurobiol, 72(5), 341-372.

Krishnan, V., Han, M.H., Graham, D.L., Berton, O., Renthal, W., Russo, S.J., Laplant, Q., Graham, A., Lutter, M., Lagace, D.C., Ghose, S., Reister, R., Tannous, P., Green, T.A., Neve, R.L., Chakravarty, S., Kumar, A., Eisch, A.J., Self, D.W., Lee, F.S., Tamminga, C.A., Cooper, D.C., Gershenfeld, H.K. \& Nestler, E.J. (2007). Molecular adaptations underlying susceptibility and resistance to social defeat in brain reward regions. Cell, 131(2), 391-404.

Krishnan, V. \& Nestler, E.J. (2008). The molecular neurobiology of depression. Nature, 455(7215), 894-902.

Krishnan, V. \& Nestler, E.J. (2010). Linking molecules to mood: New insight into the biology of depression. Am J Psychiatry, 167(11), 1305-1320.

Kunugi, H., Hattori, M., Kato, T., Tatsumi, M., Sakai, T., Sasaki, T., Hirose, T. \& Nanko, S. (1997). Serotonin transporter gene polymorphisms: Ethnic difference and possible association with bipolar affective disorder. Mol Psychiatry, 2(6), 457-462.

Kupfer, D.J., Frank, E. \& Phillips, M.L. (2012). Major depressive disorder: New clinical, neurobiological, and treatment perspectives. Lancet, 379(9820), 1045-1055.

LaBar, K.S. \& Cabeza, R. (2006). Cognitive neuroscience of emotional memory. Nat Rev Neurosci, 7(1), 54-64.

LaBar, K.S., Gatenby, J.C., Gore, J.C., LeDoux, J.E. \& Phelps, E.A. (1998). Human amygdala activation during conditioned fear 
acquisition and extinction: A mixed-trial fMRI study. Neuron, 20(5), 937-945

Lau, J.Y., Goldman, D., Buzas, B., Hodgkinson, C., Leibenluft, E., Nelson, E., Sankin, L., Pine, D.S. \& Ernst, M. (2010). BDNF gene polymorphism (Val66Met) predicts amygdala and anterior hippocampus responses to emotional faces in anxious and depressed adolescents. NeuroImage, 53(3), 952-961.

Lederbogen, F., Kirsch, P., Haddad, L., Streit, F., Tost, H., Schuch, P., Wust, S., Pruessner, J.C., Rietschel, M., Deuschle, M. \& MeyerLindenberg, A. (2011). City living and urban upbringing affect neural social stress processing in humans. Nature, 474(7352), 498-501.

LeDoux, J.E. (2000). Emotion circuits in the brain. Annu Rev Neurosci, 23, 155-184.

LeDoux, J.E. (2007). The amygdala. Curr Biol, 17(20), R868-874.

Leh, S.E., Ptito, A., Chakravarty, M.M. \& Strafella, A.P. (2007). Fronto-striatal connections in the human brain: A probabilistic diffusion tractography study. Neurosci Lett, 419(2), 113-118.

Lemogne, C., Gorwood, P., Boni, C., Pessiglione, M., Lehericy, S. \& Fossati, P. (2011). Cognitive appraisal and life stress moderate the effects of the 5-HTTLPR polymorphism on amygdala reactivity. Hum Brain Mapp, 32(11), 1856-1867.

Lemonde, S., Du, L., Bakish, D., Hrdina, P. \& Albert, P.R. (2004). Association of the C(-1019)G 5-HT1A functional promoter polymorphism with antidepressant response. Int J Neuropsychopharmacol, 7(4), 501-506.

Lesch, K.P., Bengel, D., Heils, A., Sabol, S.Z., Greenberg, B.D., Petri, S., Benjamin, J., Muller, C.R., Hamer, D.H. \& Murphy, D.L. (1996). Association of anxiety-related traits with a polymorphism in the serotonin transporter gene regulatory region. Science, 274(5292), 1527-1531.

Lesch, K.P. \& Mossner, R. (2006). Inactivation of 5HT transport in mice: Modeling altered 5HT homeostasis implicated in emotional dysfunction, affective disorders, and somatic syndromes. Handb Exp Pharmacol,175, 417-456.

Lesch, K.P. \& Waider, J. (2012). Serotonin in the modulation of neural plasticity and networks: Implications for neurodevelopmental disorders. Neuron, 76(1), 175-191.

Lessmann, V., Gottmann, K. \& Malcangio, M. (2003). Neurotrophin secretion: Current facts and future prospects. Prog Neurobiol, 69(5), 341-374.

Levenson, J.M. \& Sweatt, J.D. (2005). Epigenetic mechanisms in memory formation. Nat Rev Neurosci, 6(2), 108-118.

Levinson, D.F. (2006). The genetics of depression: A review. Biol Psychiatry, 60(2), 84-92.

Levy, B.J. \& Wagner, A.D. (2011). Cognitive control and right ventrolateral prefrontal cortex: Reflexive reorienting, motor inhibition, and action updating. Ann N Y Acad Sci, 1224, 40-62.

Licinio, J., Dong, C. \& Wong, M.L. (2009). Novel sequence variations in the brain-derived neurotrophic factor gene and association with major depression and antidepressant treatment response. Arch Gen Psychiatry, 66(5), 488-497.

Lindell, S.G., Yuan, Q., Zhou, Z., Goldman, D., Thompson, R.C., Lopez, J.F., Suomi, S.J., Higley, J.D. \& Barr, C.S. (2012). The serotonin transporter gene is a substrate for age and stress dependent epigenetic regulation in rhesus macaque brain:
Potential roles in genetic selection and Gene $\mathrm{x}$ Environment interactions. Development and Psychopathology, 24(4), 13911400.

Livneh, U. \& Paz, R. (2012). Amygdala-prefrontal synchronization underlies resistance to extinction of aversive memories. Neuron, 75(1), 133-142.

Lopez, J.F., Liberzon, I., Vazquez, D.M., Young, E.A. \& Watson, S.J. (1999). Serotonin 1A receptor messenger RNA regulation in the hippocampus after acute stress. Biol Psychiatry, 45(7), 934-937.

Lu, B., Pang, P.T. \& Woo, N.H. (2005). The yin and yang of neurotrophin action. Nat Rev Neurosci, 6(8), 603-614.

Lu, Y., Christian, K. \& Lu, B. (2008). BDNF: A key regulator for protein synthesis-dependent LTP and long-term memory? Neurobiol Learn Mem, 89(3), 312-323.

Lundberg, J., Borg, J., Halldin, C. \& Farde, L. (2007). A PET study on regional coexpression of 5-HT1A receptors and 5HTT in the human brain. Psychopharmacology (Berl), 195(3), 425-433.

Major Depressive Disorder Working Group of the Psychiatric GWAS Consortium (2012). A mega-analysis of genome-wide association studies for major depressive disorder. Mol Psychiatry, [Epub ahead of print].

Malenka, R.C. \& Bear, M.F. (2004). LTP and LTD: An embarrassment of riches. Neuron, 44(1), 5-21.

Mandelman, S.D. \& Grigorenko, E.L. (2012). BDNF Val66Met and cognition: All, none, or some? A meta-analysis of the genetic association. Genes Brain Behav, 11(2), 127-136.

Mann, J.J., Huang, Y.Y., Underwood, M.D., Kassir, S.A., Oppenheim, S., Kelly, T.M., Dwork, A.J. \& Arango, V. (2000). A serotonin transporter gene promoter polymorphism (5HTTLPR) and prefrontal cortical binding in major depression and suicide. Arch Gen Psychiatry, 57(8), 729-738.

Margulies, D.S., Kelly, A.M., Uddin, L.Q., Biswal, B.B., Castellanos, F.X. \& Milham, M.P. (2007). Mapping the functional connectivity of anterior cingulate cortex. NeuroImage, 37(2), 579-588.

Martinowich, K. \& Lu, B. (2008). Interaction between BDNF and serotonin: Role in mood disorders. Neuropsychopharmacology, 33(1), 73-83.

Masi, G. \& Brovedani, P. (2011). The hippocampus, neurotrophic factors and depression: Possible implications for the pharmacotherapy of depression. CNS Drugs, 25(11), 913-931.

Matsuo, K., Walss-Bass, C., Nery, F.G., Nicoletti, M.A., Hatch, J.P., Frey, B.N., Monkul, E.S., Zunta-Soares, G.B., Bowden, C.L., Escamilla, M.A. \& Soares, J.C. (2009). Neuronal correlates of brain-derived neurotrophic factor Val66Met polymorphism and morphometric abnormalities in bipolar disorder. Neuropsychopharmacology, 34(8), 1904-1913.

Maya Vetencourt, J.F., Sale, A., Viegi, A., Baroncelli, L., De Pasquale, R., O'Leary, O.F., Castren, E. \& Maffei, L. (2008). The antidepressant fluoxetine restores plasticity in the adult visual cortex. Science, 320(5874), 385-388.

Mayberg, H.S., Brannan, S.K., Tekell, J.L., Silva, J.A., Mahurin, R.K., McGinnis, S. \& Jerabek, P.A. (2000). Regional metabolic effects of fluoxetine in major depression: Serial changes and 
relationship to clinical response. Biol Psychiatry, 48(8), 830843.

Mayberg, H.S., Liotti, M., Brannan, S.K., McGinnis, S., Mahurin, R.K., Jerabek, P.A., Silva, J.A., Tekell, J.L., Martin, C.C., Lancaster, J.L. \& Fox, P.T. (1999). Reciprocal limbic-cortical function and negative mood: Converging PET findings in depression and normal sadness. Am J Psychiatry, 156(5), 675682 .

Mayberg, H.S., Lozano, A.M., Voon, V., McNeely, H.E., Seminowicz, D., Hamani, C., Schwalb, J.M. \& Kennedy, S.H. (2005). Deep brain stimulation for treatment-resistant depression. $\mathrm{Neu}$ ron, 45(5), 651-660.

McCabe, C. \& Mishor, Z. (2011). Antidepressant medications reduce subcortical-cortical resting-state functional connectivity in healthy volunteers. NeuroImage, 57(4), 1317-1323.

McCabe, C., Mishor, Z., Cowen, P.J. \& Harmer, C.J. (2010). Diminished neural processing of aversive and rewarding stimuli during selective serotonin reuptake inhibitor treatment. Biol Psychiatry, 67(5), 439-445.

McCormick, L.M., Boles Ponto, L.L., Pierson, R.K., Johnson, H.J., Magnotta, V. \& Brumm, M.C. (2007). Metabolic correlates of antidepressant and antipsychotic response in patients with psychotic depression undergoing electroconvulsive therapy. JECT, 23(4), 265-273.

McEwen, B.S. (2001). Plasticity of the hippocampus: Adaptation to chronic stress and allostatic load. Ann N Y Acad Sci, 933, 265-277.

McEwen, B.S., Chattarji, S., Diamond, D.M., Jay, T.M., Reagan, L.P., Svenningsson, P. \& Fuchs, E. (2010). The neurobiological properties of tianeptine (Stablon): From monoamine hypothesis to glutamatergic modulation. Mol Psychiatry, 15(3), 237-249.

McGaugh, J.L. (2000). Memory-a century of consolidation. Science, 287(5451), 248-251.

McKie, S., Del-Ben, C., Elliott, R., Williams, S., del Vai, N., Anderson, I. \& Deakin, J.F. (2005). Neuronal effects of acute citalopram detected by pharmacoMRI. Psychopharmacology (Berl), 180(4), 680-686.

Meltzer, C.C., Price, J.C., Mathis, C.A., Butters, M.A., Ziolko, S.K., Moses-Kolko, E., Mazumdar, S., Mulsant, B.H., Houck, P.R., Lopresti, B.J., Weissfeld, L.A. \& Reynolds, C.F. (2004). Serotonin $1 \mathrm{~A}$ receptor binding and treatment response in late-life depression. Neuropsychopharmacology, 29(12), 2258-2265.

Merens, W., Booij, L., Haffmans, P.J. \& van der Does, A. (2008). The effects of experimentally lowered serotonin function on emotional information processing and memory in remitted depressed patients. J Psychopharmacol, 22(6), 653-662.

Meyer-Lindenberg, A. (2012). The future of fMRI and genetics research. NeuroImage, 62(2), 1286-1292.

Meyer-Lindenberg, A. \& Weinberger, D.R. (2006). Intermediate phenotypes and genetic mechanisms of psychiatric disorders. Nat Rev Neurosci, 7(10), 818-827.

Meyer, J.H. (2007). Imaging the serotonin transporter during major depressive disorder and antidepressant treatment. J Psychiatry Neurosci, 32(2), 86-102.

Migliarini, S., Pacini, G., Pelosi, B., Lunardi, G. \& Pasqualetti, M. (2012). Lack of brain serotonin affects postnatal development and serotonergic neuronal circuitry formation. Mol Psychiatry, [Epub ahead of print].

Miller, R., Wankerl, M., Stalder, T., Kirschbaum, C. \& Alexander, N. (2012). The serotonin transporter gene-linked polymorphic region (5-HTTLPR) and cortisol stress reactivity: A metaanalysis. Mol Psychiatry, [Epub ahead of print].

Mitchell, D.G. (2011). The nexus between decision making and emotion regulation: A review of convergent neurocognitive substrates. Behav Brain Res, 217(1), 215-231.

Molendijk, M.L., Bus, B.A., Spinhoven, P., Kaimatzoglou, A., Voshaar, R.C., Penninx, B.W., van Ijzendoorn, M.H. \& Elzinga, B.M. (2012a). A systematic review and meta-analysis on the association between BDNF val(66) met and hippocampal volume-A genuine effect or a winners curse? Am J Med Genet B Neuropsychiatr Genet, 159B(6), 731-740.

Molendijk, M.L., Bus, B.A., Spinhoven, P., Penninx, B.W., Kenis, G., Prickaerts, J., Voshaar, R.C. \& Elzinga, B.M. (2011). Serum levels of brain-derived neurotrophic factor in major depressive disorder: state-trait issues, clinical features and pharmacological treatment. Mol Psychiatry, 16(11), 1088-1095.

Molendijk, M.L., Van Tol, M.J., Penninx, B.W.J.H., Van Der Wee, N.J.A., Aleman, A., Veltman, D.J., Spinhoven, P. \& Elzinga, B.M. (2012b). BDNF val 66met affects hippocampal volume and emotion-related hippocampal memory activity. Translational Psychiatry, [Epub ahead of print].

Montag, C., Reuter, M., Newport, B., Elger, C. \& Weber, B. (2008). The BDNF Val66Met polymorphism affects amygdala activity in response to emotional stimuli: Evidence from a genetic imaging study. NeuroImage, 42(4), 1554-1559.

Montag, C., Schoene-Bake, J.C., Faber, J., Reuter, M. \& Weber, B. (2010). Genetic variation on the BDNF gene is not associated with differences in white matter tracts in healthy humans measured by tract-based spatial statistics. Genes Brain Behav, 9(8), 886-891.

Monteggia, L.M., Barrot, M., Powell, C.M., Berton, O., Galanis, V., Gemelli, T., Meuth, S., Nagy, A., Greene, R.W. \& Nestler, E.J. (2004). Essential role of brain-derived neurotrophic factor in adult hippocampal function. Proc Natl Acad Sci U S A, 101(29), 10827-10832.

Moore, L.D., Le, T. \& Fan, G. (2013). DNA methylation and its basic function. Neuropsychopharmacology, 38(1), 23-38.

Morris, J.S., Frith, C.D., Perrett, D.I., Rowland, D., Young, A.W., Calder, A.J. \& Dolan, R.J. (1996). A differential neural response in the human amygdala to fearful and happy facial expressions. Nature, 383(6603), 812-815.

Morris, M.K., Bowers, D., Chatterjee, A. \& Heilman, K.M. (1992). Amnesia following a discrete basal forebrain lesion. Brain, 115 (Pt 6), 1827-1847.

Munafo, M.R., Brown, S.M. \& Hariri, A.R. (2008). Serotonin transporter (5-HTTLPR) genotype and amygdala activation: A meta-analysis. Biol Psychiatry, 63(9), 852-857.

Munafo, M.R., Durrant, C., Lewis, G. \& Flint, J. (2009). Gene X environment interactions at the serotonin transporter locus. Biol Psychiatry, 65(3), 211-219.

Murphy, D.L., Fox, M.A., Timpano, K.R., Moya, P.R., RenPatterson, R., Andrews, A.M., Holmes, A., Lesch, K.P. \& Wendland, J.R. (2008). How the serotonin story is being 
rewritten by new gene-based discoveries principally related to SLC6A4, the serotonin transporter gene, which functions to influence all cellular serotonin systems. Neuropharmacology, 55(6), 932-960.

Murphy, D.L. \& Lesch, K.P. (2008). Targeting the murine serotonin transporter: Insights into human neurobiology. Nat Rev Neurosci, 9(2), 85-96.

Murphy, D.L., Uhl, G.R., Holmes, A., Ren-Patterson, R., Hall, F.S., Sora, I., Detera-Wadleigh, S. \& Lesch, K.P. (2003). Experimental gene interaction studies with SERT mutant mice as models for human polygenic and epistatic traits and disorders. Genes Brain Behav, 2(6), 350-364.

Murphy, F.C., Smith, K.A., Cowen, P.J., Robbins, T.W. \& Sahakian, B.J. (2002). The effects of tryptophan depletion on cognitive and affective processing in healthy volunteers. Psychopharmacology, 163(1), 42-53.

Murphy, S.E., Norbury, R., Godlewska, B.R., Cowen, P.J., Mannie, Z.M., Harmer, C.J. \& Munafo, M.R. (2012). The effect of the serotonin transporter polymorphism (5-HTTLPR) on amygdala function: A meta-analysis. Mol Psychiatry.

Murray, E.A., Wise, S.P. \& Drevets, W.C. (2011). Localization of dysfunction in major depressive disorder: Prefrontal cortex and amygdala. Biol Psychiatry, 69(12), e43-54.

Murthy, N.V., Selvaraj, S., Cowen, P.J., Bhagwagar, Z., Riedel, W.J., Peers, P., Kennedy, J.L., Sahakian, B.J., Laruelle, M.A., Rabiner, E.A. \& Grasby, P.M. (2010). Serotonin transporter polymorphisms (SLC6A4 insertion/deletion and rs25531) do not affect the availability of 5-HTT to [11C] DASB binding in the living human brain. NeuroImage, 52(1), 50-54.

Nagahara, A.H. \& Tuszynski, M.H. (2011). Potential therapeutic uses of BDNF in neurological and psychiatric disorders. Nat Rev Drug Discov, 10(3), 209-219.

Nederhof, E., Bouma, E.M., Oldehinkel, A.J. \& Ormel, J. (2010a). Interaction between childhood adversity, brain-derived neurotrophic factor $\mathrm{val} / \mathrm{met}$ and serotonin transporter promoter polymorphism on depression: The TRAILS study. Biol Psychiatry, 68(2), 209-212.

Nederhof, E., Bouma, E.M., Riese, H., Laceulle, O.M., Ormel, J. \& Oldehinkel, A.J. (2010b). Evidence for plasticity genotypes in a gene-gene-environment interaction: The TRAILS study. Genes Brain Behav, 9(8), 968-973.

Nemoto, K., Ohnishi, T., Mori, T., Moriguchi, Y., Hashimoto, R., Asada, T. \& Kunugi, H. (2006). The Val66Met polymorphism of the brain-derived neurotrophic factor gene affects age-related brain morphology. Neurosci Lett, 397(1-2), 25-29.

Nestler, E.J., Barrot, M., DiLeone, R.J., Eisch, A.J., Gold, S.J. \& Monteggia, L.M. (2002). Neurobiology of depression. Neuron, 34(1), 13-25.

Neumeister, A., Nugent, A.C., Waldeck, T., Geraci, M., Schwarz, M., Bonne, O., Bain, E.E., Luckenbaugh, D.A., Herscovitch, P., Charney, D.S. \& Drevets, W.C. (2004). Neural and behavioral responses to tryptophan depletion in unmedicated patients with remitted major depressive disorder and controls. Arch Gen Psychiatry, 61(8), 765-773.

Nichols, D.E. \& Nichols, C.D. (2008). Serotonin receptors. Chem Rev, 108(5), 1614-1641.
Novak, N.M., Stein, J.L., Medland, S.E., Hibar, D.P., Thompson, P.M. \& Toga, A.W. (2012). EnigmaVis: Online interactive visualization of genome-wide association studies of the Enhancing NeuroImaging Genetics through Meta-Analysis (ENIGMA) consortium. Twin Res Hum Genet, 15(3), 414-418.

Nutt, D.J. (2008). Relationship of neurotransmitters to the symptoms of major depressive disorder. J Clin Psychiatry, 69 Suppl E1, 4-7.

O’Nions, E.J., Dolan, R.J. \& Roiser, J.P. (2011). Serotonin transporter genotype modulates subgenual response to fearful faces using an incidental task. J Cogn Neurosci, 23(11), 3681-3693.

O'Rourke, H. \& Fudge, J.L. (2006). Distribution of serotonin transporter labeled fibers in amygdaloid subregions: Implications for mood disorders. Biol Psychiatry, 60(5), 479-490.

Ochsner, K.N., Ray, R.D., Cooper, J.C., Robertson, E.R., Chopra, S., Gabrieli, J.D. \& Gross, J.J. (2004). For better or for worse: Neural systems supporting the cognitive down- and up-regulation of negative emotion. NeuroImage, 23(2), 483-499.

Oldehinkel, A.J., Hartman, C.A., Nederhof, E., Riese, H. \& Ormel, J. (2011). Effortful control as predictor of adolescents' psychological and physiological responses to a social stress test: The Tracking Adolescents' Individual Lives Survey. Development and Psychopathology, 23(2), 679-688.

Ongur, D., Drevets, W.C. \& Price, J.L. (1998). Glial reduction in the subgenual prefrontal cortex in mood disorders. Proc Natl Acad Sci U S A, 95(22), 13290-13295.

Palomero-Gallagher, N., Vogt, B.A., Schleicher, A., Mayberg, H.S. \& Zilles, K. (2009). Receptor architecture of human cingulate cortex: Evaluation of the four-region neurobiological model. Hum Brain Mapp, 30(8), 2336-2355.

Parsey, R.V., Hastings, R.S., Oquendo, M.A., Hu, X., Goldman, D., Huang, Y.Y., Simpson, N., Arcement, J., Huang, Y., Ogden, R.T., Van Heertum, R.L., Arango, V. \& Mann, J.J. (2006). Effect of a triallelic functional polymorphism of the serotonintransporter-linked promoter region on expression of serotonin transporter in the human brain. Am J Psychiatry, 163(1), 48-51.

Pezawas, L. \& Meyer-Lindenberg, A. (2010). Imaging genetics: Progressing by leaps and bounds. NeuroImage, 53(3), 801-803.

Pezawas, L., Meyer-Lindenberg, A., Drabant, E.M., Verchinski, B.A., Munoz, K.E., Kolachana, B.S., Egan, M.F., Mattay, V.S., Hariri, A.R. \& Weinberger, D.R. (2005). 5-HTTLPR polymorphism impacts human cingulate-amygdala interactions: A genetic susceptibility mechanism for depression. Nat Neurosci, $8(6), 828-834$.

Pezawas, L., Meyer-Lindenberg, A., Goldman, A.L., Verchinski, B.A., Chen, G., Kolachana, B.S., Egan, M.F., Mattay, V.S., Hariri, A.R. \& Weinberger, D.R. (2008). Evidence of biologic epistasis between BDNF and SLC6A4 and implications for depression. Mol Psychiatry, 13(7), 709-716.

Pezawas, L., Verchinski, B.A., Mattay, V.S., Callicott, J.H., Kolachana, B.S., Straub, R.E., Egan, M.F., Meyer-Lindenberg, A. \& Weinberger, D.R. (2004). The brain-derived neurotrophic factor val66met polymorphism and variation in human cortical morphology. J Neurosci, 24(45), 10099-10102.

Phillips, M.L., Drevets, W.C., Rauch, S.L. \& Lane, R. (2003a). Neurobiology of emotion perception I: The neural basis of normal emotion perception. Biol Psychiatry, 54(5), 504-514. 
Phillips, M.L., Drevets, W.C., Rauch, S.L. \& Lane, R. (2003b). Neurobiology of emotion perception II: Implications for major psychiatric disorders. Biol Psychiatry, 54(5), 515-528.

Piccinni, A., Marazziti, D., Catena, M., Domenici, L., Del Debbio, A., Bianchi, C., Mannari, C., Martini, C., Da Pozzo, E., Schiavi, E., Mariotti, A., Roncaglia, I., Palla, A., Consoli, G., Giovannini, L., Massimetti, G. \& Dell'Osso, L. (2008). Plasma and serum brain-derived neurotrophic factor (BDNF) in depressed patients during 1 year of antidepressant treatments. $J$ Affect Disord, 105(1-3), 279-283.

Pittenger, C. \& Duman, R.S. (2008). Stress, depression, and neuroplasticity: A convergence of mechanisms. Neuropsychopharmacology, 33(1), 88-109.

Pizzagalli, D.A. (2011). Frontocingulate dysfunction in depression: Toward biomarkers of treatment response. Neuropsychopharmacology, 36(1), 183-206.

Poo, M.M. (2001). Neurotrophins as synaptic modulators. Nat Rev Neurosci, 2(1), 24-32.

Post, R.M. (2007). Kindling and sensitization as models for affective episode recurrence, cyclicity, and tolerance phenomena. Neurosci Biobehav Rev, 31(6), 858-873.

Potkin, S.G., Guffanti, G., Lakatos, A., Turner, J.A., Kruggel, F., Fallon, J.H., Saykin, A.J., Orro, A., Lupoli, S., Salvi, E., Weiner, M., Macciardi, F. \& Alzheimer's Disease Neuroimaging, I. (2009). Hippocampal atrophy as a quantitative trait in a genome-wide association study identifying novel susceptibility genes for Alzheimer's disease. PLoS One, 4(8), e6501.

Preece, M.A., Taylor, M.J., Raley, J., Blamire, A., Sharp, T. \& Sibson, N.R. (2009). Evidence that increased 5-HT release evokes region-specific effects on blood-oxygenation level-dependent functional magnetic resonance imaging responses in the rat brain. Neuroscience, 159(2), 751-759.

Price, J.L. \& Drevets, W.C. (2010). Neurocircuitry of mood disorders. Neuropsychopharmacology, 35(1), 192-216.

Price, J.L. \& Drevets, W.C. (2012). Neural circuits underlying the pathophysiology of mood disorders. Trends Cogn Sci, 16(1), 61-71.

Puckett, R.E. \& Lubin, F.D. (2011). Epigenetic mechanisms in experience-driven memory formation and behavior. Epigenomics, 3(5), 649-664.

Puig, M.V. \& Gulledge, A.T. (2011). Serotonin and prefrontal cortex function: Neurons, networks, and circuits. Mol Neurobiol, 44(3), 449-464.

Rabl, U., Scharinger, C., Muller, M. \& Pezawas, L. (2010). Imaging genetics: Implications for research on variable antidepressant drug response. Expert Rev Clin Pharmacol, 3(4), 471-489.

Rao, H., Gillihan, S.J., Wang, J., Korczykowski, M., Sankoorikal, G.M., Kaercher, K.A., Brodkin, E.S., Detre, J.A. \& Farah, M.J (2007). Genetic variation in serotonin transporter alters resting brain function in healthy individuals. Biol Psychiatry, 62(6), 600-606.

Ren-Patterson, R.F., Cochran, L.W., Holmes, A., Sherrill, S., Huang, S.J., Tolliver, T., Lesch, K.P., Lu, B. \& Murphy, D.L. (2005). Loss of brain-derived neurotrophic factor gene allele exacerbates brain monoamine deficiencies and increases stress abnormalities of serotonin transporter knockout mice. $\mathrm{J} \mathrm{Neu}$ rosci Res, 79(6), 756-771.
Riccio, O., Potter, G., Walzer, C., Vallet, P., Szabo, G., Vutskits, L., Kiss, J.Z. \& Dayer, A.G. (2009). Excess of serotonin affects embryonic interneuron migration through activation of the serotonin receptor 6. Mol Psychiatry, 14(3), 280-290.

Richardson-Jones, J.W., Craige, C.P., Guiard, B.P., Stephen, A., Metzger, K.L., Kung, H.F., Gardier, A.M., Dranovsky, A., David, D.J., Beck, S.G., Hen, R. \& Leonardo, E.D. (2010). 5-HT1A autoreceptor levels determine vulnerability to stress and response to antidepressants. Neuron, 65(1), 40-52.

Richter-Schmidinger, T., Alexopoulos, P., Horn, M., Maus, S., Reichel, M., Rhein, C., Lewczuk, P., Sidiropoulos, C., Kneib, T., Perneczky, R., Doerfler, A. \& Kornhuber, J. (2011). Influence of brain-derived neurotrophic-factor and apolipoprotein E genetic variants on hippocampal volume and memory performance in healthy young adults. J Neural Transm, 118(2), 249-257.

Risch, N., Herrell, R., Lehner, T., Liang, K.Y., Eaves, L., Hoh, J., Griem, A., Kovacs, M., Ott, J. \& Merikangas, K.R. (2009). Interaction between the serotonin transporter gene (5HTTLPR), stressful life events, and risk of depression: A meta-analysis. JAMA, 301(23), 2462-2471.

Robinson, O.J., Overstreet, C., Allen, P.S., Pine, D.S. \& Grillon, C. (2012). Acute tryptophan depletion increases translational indices of anxiety but not fear: serotonergic modulation of the bed nucleus of the stria terminalis? Neuropsychopharmacology, 37(8), 1963-1971.

Rogers, R.D., Blackshaw, A.J., Middleton, H.C., Matthews, K., Hawtin, K., Crowley, C., Hopwood, A., Wallace, C., Deakin, J.F., Sahakian, B.J. \& Robbins, T.W. (1999). Tryptophan depletion impairs stimulus-reward learning while methylphenidate disrupts attentional control in healthy young adults: Implications for the monoaminergic basis of impulsive behaviour. Psychopharmacology, 146(4), 482-491.

Roiser, J.P., de Martino, B., Tan, G.C., Kumaran, D., Seymour, B., Wood, N.W. \& Dolan, R.J. (2009). A genetically mediated bias in decision making driven by failure of amygdala control. $J$ Neurosci, 29(18), 5985-5991.

Rolls, E.T. (2007). An attractor network in the hippocampus: Theory and neurophysiology. Learn Mem, 14(11), 714-731.

Rolls, E.T. \& Grabenhorst, F. (2008). The orbitofrontal cortex and beyond: From affect to decision-making. Prog Neurobiol, 86(3), 216-244.

Rolls, E.T. \& Kesner, R.P. (2006). A computational theory of hippocampal function, and empirical tests of the theory. Prog Neurobiol, 79(1), 1-48.

Roozendaal, B., McEwen, B.S. \& Chattarji, S. (2009). Stress, memory and the amygdala. Nat Rev Neurosci, 10(6), 423-433.

Rose, E.J., Simonotto, E., Spencer, E.P. \& Ebmeier, K.P. (2006). The effects of escitalopram on working memory and brain activity in healthy adults during performance of the n-back task. Psychopharmacology, 185(3), 339-347.

Rowe, J.B., Toni, I., Josephs, O., Frackowiak, R.S. \& Passingham, R.E. (2000). The prefrontal cortex: Response selection or maintenance within working memory? Science, 288(5471), 1656-1660.

Ruhe, H.G., Booij, J., Veltman, D.J., Michel, M.C. \& Schene, A.H. (2012). Successful pharmacologic treatment of major depres- 
sive disorder attenuates amygdala activation to negative facial expressions: A functional magnetic resonance imaging study. $J$ Clin Psychiatry, 73(4), 451-459.

Ruhe, H.G., Mason, N.S. \& Schene, A.H. (2007). Mood is indirectly related to serotonin, norepinephrine and dopamine levels in humans: A meta-analysis of monoamine depletion studies. Mol Psychiatry, 12(4), 331-359.

Rushworth, M.F., Behrens, T.E., Rudebeck, P.H. \& Walton, M.E. (2007). Contrasting roles for cingulate and orbitofrontal cortex in decisions and social behaviour. Trends Cogn Sci, 11(4), 168176.

Saarelainen, T., Hendolin, P., Lucas, G., Koponen, E., Sairanen, M., MacDonald, E., Agerman, K., Haapasalo, A., Nawa, H., Aloyz, R., Ernfors, P. \& Castren, E. (2003). Activation of the TrkB neurotrophin receptor is induced by antidepressant drugs and is required for antidepressant-induced behavioral effects. $J$ Neurosci, 23(1), 349-357.

Sakagami, M. \& Pan, X. (2007). Functional role of the ventrolateral prefrontal cortex in decision making. Curr Opin Neurobiol, 17(2), 228-233.

Saulin, A., Savli, M. \& Lanzenberger, R. (2012). Serotonin and molecular neuroimaging in humans using PET. Amino Acids, 42(6), 2039-2057.

Saxe, M.D., Battaglia, F., Wang, J.W., Malleret, G., David, D.J., Monckton, J.E., Garcia, A.D., Sofroniew, M.V., Kandel, E.R., Santarelli, L., Hen, R. \& Drew, M.R. (2006). Ablation of hippocampal neurogenesis impairs contextual fear conditioning and synaptic plasticity in the dentate gyrus. Proc Natl Acad Sci U S A, 103(46), 17501-17506.

Scharinger, C., Rabl, U., Sitte, H.H. \& Pezawas, L. (2010). Imaging genetics of mood disorders. NeuroImage, 53(3), 810-821.

Schinka, J.A., Busch, R.M. \& Robichaux-Keene, N. (2004). A metaanalysis of the association between the serotonin transporter gene polymorphism (5-HTTLPR) and trait anxiety. Mol Psychiatry, 9(2), 197-202.

Schmidt, H.D., Shelton, R.C. \& Duman, R.S. (2011). Functional Biomarkers of Depression: Diagnosis, Treatment, and Pathophysiology. Neuropsychopharmacology, 36(12), 2375-2394.

Schofield, P.R., Williams, L.M., Paul, R.H., Gatt, J.M., Brown, K., Luty, A., Cooper, N., Grieve, S., Dobson-Stone, C., Morris, C., Kuan, S.A. \& Gordon, E. (2009). Disturbances in selective information processing associated with the BDNF Val66Met polymorphism: Evidence from cognition, the P300 and frontohippocampal systems. Biol Psychol, 80(2), 176-188.

Schumann, G., Loth, E., Banaschewski, T., Barbot, A., Barker, G., Buchel, C., Conrod, P.J., Dalley, J.W., Flor, H., Gallinat, J., Garavan, H., Heinz, A., Itterman, B., Lathrop, M., Mallik, C., Mann, K., Martinot, J.L., Paus, T., Poline, J.B., Robbins, T.W., Rietschel, M., Reed, L., Smolka, M., Spanagel, R., Speiser, C., Stephens, D.N., Strohle, A., Struve, M. \& consortium, I. (2010). The IMAGEN study: Reinforcement-related behaviour in normal brain function and psychopathology. Mol Psychiatry, 15(12), 1128-1139.

Selvaraj, S., Godlewska, B.R., Norbury, R., Bose, S., Turkheimer, F., Stokes, P., Rhodes, R., Howes, O. \& Cowen, P.J. (2011). Decreased regional gray matter volume in $S$ ' allele carriers of the 5-HTTLPR triallelic polymorphism. Mol Psychiatry, 16(5), $471,472-473$.
Sen, S., Burmeister, M. \& Ghosh, D. (2004). Meta-analysis of the association between a serotonin transporter promoter polymorphism (5-HTTLPR) and anxiety-related personality traits. Am J Med Genet B Neuropsychiatr Genet, 127B(1), 85-89.

Serretti, A., Olgiati, P., Bajo, E., Bigelli, M. \& De Ronchi, D. (2011). A model to incorporate genetic testing (5-HTTLPR) in pharmacological treatment of major depressive disorders. World $J$ Biol Psychiatry, 12(7), 501-515.

Shah, M.P., Wang, F., Kalmar, J.H., Chepenik, L.G., Tie, K., Pittman, B., Jones, M.M., Constable, R.T., Gelernter, J. \& Blumberg, H.P. (2009). Role of variation in the serotonin transporter protein gene (SLC6A4) in trait disturbances in the ventral anterior cingulate in bipolar disorder. Neuropsychopharmacology, 34(5), 1301-1310.

Sheth, S.A., Mian, M.K., Patel, S.R., Asaad, W.F., Williams, Z.M., Dougherty, D.D., Bush, G. \& Eskandar, E.N. (2012). Human dorsal anterior cingulate cortex neurons mediate ongoing behavioural adaptation. Nature, 488(7410), 218-221.

Shifman, S., Bhomra, A., Smiley, S., Wray, N.R., James, M.R., Martin, N.G., Hettema, J.M., An, S.S., Neale, M.C., van den Oord, E.J., Kendler, K.S., Chen, X., Boomsma, D.I., Middeldorp, C.M., Hottenga, J.J., Slagboom, P.E. \& Flint, J. (2008). A whole genome association study of neuroticism using DNA pooling. Mol Psychiatry, 13(3), 302-312.

Shioe, K., Ichimiya, T., Suhara, T., Takano, A., Sudo, Y., Yasuno, F., Hirano, M., Shinohara, M., Kagami, M., Okubo, Y., Nankai, M. \& Kanba, S. (2003). No association between genotype of the promoter region of serotonin transporter gene and serotonin transporter binding in human brain measured by PET. Synapse, 48(4), 184-188

Skipper, M. (2011). Epigenomics: Epigenetic variation across the generations. Nat Rev Genet, 12(11), 740.

Smolka, M.N., Buhler, M., Schumann, G., Klein, S., Hu, X.Z., Moayer, M., Zimmer, A., Wrase, J., Flor, H., Mann, K., Braus, D.F., Goldman, D. \& Heinz, A. (2007). Gene-gene effects on central processing of aversive stimuli. Mol Psychiatry, 12(3), 307-317.

Soliman, F., Glatt, C.E., Bath, K.G., Levita, L., Jones, R.M., Pattwell, S.S., Jing, D., Tottenham, N., Amso, D., Somerville, L.H., Voss, H.U., Glover, G., Ballon, D.J., Liston, C., Teslovich, T., Van Kempen, T., Lee, F.S. \& Casey, B.J. (2010). A genetic variant BDNF polymorphism alters extinction learning in both mouse and human. Science, 327(5967), 863-866.

Spindelegger, C., Lanzenberger, R., Wadsak, W., Mien, L.K., Stein, P., Mitterhauser, M., Moser, U., Holik, A., Pezawas, L., Kletter, K. \& Kasper, S. (2009). Influence of escitalopram treatment on 5-HT 1A receptor binding in limbic regions in patients with anxiety disorders. Mol Psychiatry, 14(11), 1040-1050.

Stein, J.L., Medland, S.E., Vasquez, A.A., Hibar, D.P., Senstad, R.E., Winkler, A.M., Toro, R., Appel, K., Bartecek, R., Bergmann, O., Bernard, M., Brown, A.A., Cannon, D.M., Chakravarty, M.M., Christoforou, A., Domin, M., Grimm, O., Hollinshead, M., Holmes, A.J., Homuth, G., Hottenga, J.J., Langan, C., Lopez, L.M., Hansell, N.K., Hwang, K.S., Kim, S., Laje, G., Lee, P.H., Liu, X., Loth, E., Lourdusamy, A., Mattingsdal, M., Mohnke, S., Maniega, S.M., Nho, K., Nugent, A.C., O'Brien, C., Papmeyer, M., Putz, B., Ramasamy, A., Rasmussen, J., Rijpkema, M., Risacher, S.L., Roddey, J.C., Rose, E.J., Ryten, 
M., Shen, L., Sprooten, E., Strengman, E., Teumer, A., Trabzuni, D., Turner, J., van Eijk, K., van Erp, T.G., van Tol, M.J., Wittfeld, K., Wolf, C., Woudstra, S., Aleman, A., Alhusaini, S., Almasy, L., Binder, E.B., Brohawn, D.G., Cantor, R.M., Carless, M.A., Corvin, A., Czisch, M., Curran, J.E., Davies, G., de Almeida, M.A., Delanty, N., Depondt, C., Duggirala, R., Dyer, T.D., Erk, S., Fagerness, J., Fox, P.T., Freimer, N.B., Gill, M., Goring, H.H., Hagler, D.J., Hoehn, D., Holsboer, F., Hoogman, M., Hosten, N., Jahanshad, N., Johnson, M.P., Kasperaviciute, D., Kent, J.W., Jr., Kochunov, P., Lancaster, J.L., Lawrie, S.M., Liewald, D.C., Mandl, R., Matarin, M., Mattheisen, M., Meisenzahl, E., Melle, I., Moses, E.K., Muhleisen, T.W., Nauck, M., Nothen, M.M., Olvera, R.L., Pandolfo, M., Pike, G.B., Puls, R., Reinvang, I., Renteria, M.E., Rietschel, M., Roffman, J.L., Royle, N.A., Rujescu, D., Savitz, J., Schnack, H.G., Schnell, K., Seiferth, N., Smith, C. Steen, V.M., Valdes Hernandez, M.C., Van den Heuvel, M., van der Wee, N.J., Van Haren, N.E., Veltman, J.A., Volzke, H., Walker, R., Westlye, L.T., Whelan, C.D., Agartz, I., Boomsma, D.I., Cavalleri, G.L., Dale, A.M., Djurovic, S., Drevets, W.C., Hagoort, P., Hall, J., Heinz, A., Jack, C.R., Jr., Foroud, T.M., Le Hellard, S., Macciardi, F., Montgomery, G.W., Poline, J.B., Porteous, D.J., Sisodiya, S.M., Starr, J.M., Sussmann, J., Toga, A.W., Veltman, D.J., Walter, H., Weiner, M.W., Alzheimer's Disease Neuroimaging, I., Consortium, E., Consortium, I., Saguenay Youth Study, G., Bis, J.C., Ikram, M.A., Smith, A.V., Gudnason, V., Tzourio, C., Vernooij, M.W., Launer, L.J., DeCarli, C., Seshadri, S., Cohorts for, H., Aging Research in Genomic Epidemiology, C., Andreassen, O.A., Apostolova, L.G., Bastin, M.E., Blangero, J., Brunner, H.G., Buckner, R.L., Cichon, S., Coppola, G., de Zubicaray, G.I., Deary, I.J., Donohoe, G., de Geus, E.J., Espeseth, T., Fernandez, G., Glahn, D.C., Grabe, H.J., Hardy, J., Hulshoff Pol, H.E., Jenkinson, M., Kahn, R.S., McDonald, C., McIntosh, A.M., McMahon, F.J., McMahon, K.L., Meyer-Lindenberg, A., Morris, D.W., MullerMyhsok, B., Nichols, T.E., Ophoff, R.A., Paus, T., Pausova, Z. Penninx, B.W., Potkin, S.G., Samann, P.G., Saykin, A.J., Schumann, G., Smoller, J.W., Wardlaw, J.M., Weale, M.E., Martin, N.G., Franke, B., Wright, M.J., Thompson, P.M. \& Enhancing Neuro Imaging Genetics through Meta-Analysis, C. (2012). Identification of common variants associated with human hippocampal and intracranial volumes. Nat Genet, 44(5), 552-561.

Sublette, M.E., Baca-Garcia, E., Parsey, R.V., Oquendo, M.A., Rodrigues, S.M., Galfalvy, H., Huang, Y.Y., Arango, V. \& Mann, J.J. (2008). Effect of BDNF val66met polymorphism on age-related amygdala volume changes in healthy subjects. Prog Neuropsychopharmacol Biol Psychiatry, 32(7), 16521655.

Sullivan, P.F., de Geus, E.J., Willemsen, G., James, M.R., Smit, J.H., Zandbelt, T., Arolt, V., Baune, B.T., Blackwood, D., Cichon, S., Coventry, W.L., Domschke, K., Farmer, A., Fava, M., Gordon, S.D., He, Q., Heath, A.C., Heutink, P., Holsboer, F., Hoogendijk, W.J., Hottenga, J.J., Hu, Y., Kohli, M., Lin, D., Lucae, S., Macintyre, D.J., Maier, W., McGhee, K.A., McGuffin, P., Montgomery, G.W., Muir, W.J., Nolen, W.A., Nothen, M.M., Perlis, R.H., Pirlo, K., Posthuma, D., Rietschel, M., Rizzu, P., Schosser, A., Smit, A.B., Smoller, J.W., Tzeng, J.Y., van Dyck, R., Verhage, M., Zitman, F.G., Martin, N.G., Wray, N.R., Boomsma, D.I. \& Penninx, B.W. (2009). Genome-wide association for major depressive disorder: A possible role for the presynaptic protein piccolo. Mol Psychiatry, 14(4), 359-375.
Sultan, F.A. \& Day, J.J. (2011). Epigenetic mechanisms in memory and synaptic function. Epigenomics, 3(2), 157-181.

Surguladze, S.A., Elkin, A., Ecker, C., Kalidindi, S., Corsico, A., Giampietro, V., Lawrence, N., Deeley, Q., Murphy, D.G., Kucharska-Pietura, K., Russell, T.A., McGuffin, P., Murray, R. \& Phillips, M.L. (2008). Genetic variation in the serotonin transporter modulates neural system-wide response to fearful faces. Genes Brain Behav, 7(5), 543-551.

Szeszko, P.R., Lipsky, R., Mentschel, C., Robinson, D., GunduzBruce, H., Sevy, S., Ashtari, M., Napolitano, B., Bilder, R.M., Kane, J.M., Goldman, D. \& Malhotra, A.K. (2005). Brain-derived neurotrophic factor val66met polymorphism and volume of the hippocampal formation. Mol Psychiatry, 10(7), 631-636.

Tsankova, N., Renthal, W., Kumar, A. \& Nestler, E.J. (2007). Epigenetic regulation in psychiatric disorders. Nat Rev Neurosci, 8(5), 355-367.

Unternaehrer, E., Luers, P., Mill, J., Dempster, E., Meyer, A.H., Staehli, S., Lieb, R., Hellhammer, D.H. \& Meinlschmidt, G. (2012). Dynamic changes in DNA methylation of stressassociated genes (OXTR, BDNF) after acute psychosocial stress. Transl Psychiatry, 2, [Epub ahead of print].

van IJzendoorn, M.H., Caspers, K., Bakermans-Kranenburg, M.J., Beach, S.R. \& Philibert, R. (2010). Methylation matters: Interaction between methylation density and serotonin transporter genotype predicts unresolved loss or trauma. Biol Psychiatry, 68(5), 405-407.

van Wingen, G., Rijpkema, M., Franke, B., van Eijndhoven, P., Tendolkar, I., Verkes, R.J., Buitelaar, J. \& Fernandez, G. (2010). The brain-derived neurotrophic factor Val66Met polymorphism affects memory formation and retrieval of biologically salient stimuli. NeuroImage, 50(3), 1212-1218.

Varnas, K., Halldin, C. \& Hall, H. (2004). Autoradiographic distribution of serotonin transporters and receptor subtypes in human brain. Hum Brain Mapp, 22(3), 246-260.

Vogt, B.A. (2005). Pain and emotion interactions in subregions of the cingulate gyrus. Nat Rev Neurosci, 6(7), 533-544.

Vogt, B.A. (2009). Cingulate Neurobiology and Disease: Oxford University Press.

von dem Hagen, E.A., Passamonti, L., Nutland, S., Sambrook, J. \& Calder, A.J. (2011). The serotonin transporter gene polymorphism and the effect of baseline on amygdala response to emotional faces. Neuropsychologia, 49(4), 674-680.

Vythilingam, M., Vermetten, E., Anderson, G.M., Luckenbaugh, D., Anderson, E.R., Snow, J., Staib, L.H., Charney, D.S. \& Bremner, J.D. (2004). Hippocampal volume, memory, and cortisol status in major depressive disorder: Effects of treatment. Biol Psychiatry, 56(2), 101-112.

Wang, L., Ashley-Koch, A., Steffens, D.C., Krishnan, K.R. \& Taylor, W.D. (2012). Impact of BDNF Val66Met and 5-HTTLPR polymorphism variants on neural substrates related to sadness and executive function. Genes Brain Behav, 11(3), 352-359.

Wells, T.T., Beevers, C.G. \& McGeary, J.E. (2010). Serotonin transporter and BDNF genetic variants interact to predict cognitive reactivity in healthy adults. J Affect Disord, 126(1-2), 223-229.

Whalen, P.J., Rauch, S.L., Etcoff, N.L., McInerney, S.C., Lee, M.B. \& Jenike, M.A. (1998). Masked presentations of emotional 
facial expressions modulate amygdala activity without explicit knowledge. J Neurosci, 18(1), 411-418.

Whelan, R., Conrod, P.J., Poline, J.B., Lourdusamy, A., Banaschewski, T., Barker, G.J., Bellgrove, M.A., Buchel, C., Byrne, M., Cummins, T.D., Fauth-Buhler, M., Flor, H., Gallinat, J., Heinz, A., Ittermann, B., Mann, K., Martinot, J.L., Lalor, E.C., Lathrop, M., Loth, E., Nees, F., Paus, T., Rietschel, M., Smolka, M.N., Spanagel, R., Stephens, D.N., Struve, M., Thyreau, B., Vollstaedt-Klein, S., Robbins, T.W., Schumann, G., Garavan, H. \& Consortium, I. (2012). Adolescent impulsivity phenotypes characterized by distinct brain networks. Nat Neurosci, 15(6), 920-925.

Wichers, M., Kenis, G., Jacobs, N., Mengelers, R., Derom, C., Vlietinck, R. \& van Os, J. (2008). The BDNF Val(66)Met $\mathrm{x}$ 5-HTTLPR $\mathrm{x}$ child adversity interaction and depressive symptoms: An attempt at replication. Am J Med Genet B Neuropsychiatr Genet, 147B(1), 120-123.

Wiers, C.E. (2012). Methylation and the human brain: Towards a new discipline of imaging epigenetics. Eur Arch Psychiatry Clin Neurosci, 262(3), 271-273.

Willeit, M., Sitte, H.H., Thierry, N., Michalek, K., Praschak-Rieder, N., Zill, P., Winkler, D., Brannath, W., Fischer, M.B., Bondy, B., Kasper, S. \& Singer, E.A. (2008). Enhanced serotonin transporter function during depression in seasonal affective disorder. Neuropsychopharmacology, 33(7), 1503-1513.

Windischberger, C., Lanzenberger, R., Holik, A., Spindelegger, C., Stein, P., Moser, U., Gerstl, F., Fink, M., Moser, E. \& Kasper, S. (2010). Area-specific modulation of neural activation comparing escitalopram and citalopram revealed by pharmaco-fMRI: A randomized cross-over study. NeuroImage, 49(2), 11611170 .

Wong, M.L. \& Licinio, J. (2001). Research and treatment approaches to depression. Nat Rev Neurosci, 2(5), 343-351.

Wray, N.R., Pergadia, M.L., Blackwood, D.H., Penninx, B.W., Gordon, S.D., Nyholt, D.R., Ripke, S., MacIntyre, D.J., McGhee,
K.A., Maclean, A.W., Smit, J.H., Hottenga, J.J., Willemsen, G., Middeldorp, C.M., de Geus, E.J., Lewis, C.M., McGuffin, P., Hickie, I.B., van den Oord, E.J., Liu, J.Z., Macgregor, S., McEvoy, B.P., Byrne, E.M., Medland, S.E., Statham, D.J., Henders, A.K., Heath, A.C., Montgomery, G.W., Martin, N.G., Boomsma, D.I., Madden, P.A. \& Sullivan, P.F. (2012). Genomewide association study of major depressive disorder: New results, meta-analysis, and lessons learned. Mol Psychiatry, 17(1), 36-48.

Xie, P., Kranzler, H.R., Farrer, L. \& Gelernter, J. (2012). Serotonin transporter 5-HTTLPR genotype moderates the effects of childhood adversity on posttraumatic stress disorder risk: A replication study. Am J Med Genet B Neuropsychiatr Genet, 159B(6), 644-652.

Yarkoni, T., Poldrack, R.A., Nichols, T.E., Van Essen, D.C. \& Wager, T.D. (2011). Large-scale automated synthesis of human functional neuroimaging data. Nat Methods, 8(8), 665-670.

Yokoyama, C., Yamanaka, H., Onoe, K., Kawasaki, A., Nagata, H., Shirakami, K., Doi, H. \& Onoe, H. (2010). Mapping of serotonin transporters by positron emission tomography with [11C]DASB in conscious common marmosets: Comparison with rhesus monkeys. Synapse, 64(8), 594-601.

Youdim, M.B., Edmondson, D. \& Tipton, K.F. (2006). The therapeutic potential of monoamine oxidase inhibitors. Nat Rev Neurosci, 7(4), 295-309.

Yu, H., Wang, D.D., Wang, Y., Liu, T., Lee, F.S. \& Chen, Z.Y. (2012). Variant brain-derived neurotrophic factor Val66Met polymorphism alters vulnerability to stress and response to antidepressants. J Neurosci, 32(12), 4092-4101.

Yucel, K., McKinnon, M.C., Chahal, R., Taylor, V.H., Macdonald, K., Joffe, R. \& MacQueen, G.M. (2008). Anterior cingulate volumes in never-treated patients with major depressive disorder. Neuropsychopharmacology, 33(13), 3157-3163. 